Article

\title{
Optimization of Piston Grooves, Bridges on Cylinder Head, and Inlet Valve Masking of Home-Fueled Diesel Engine by Response Surface Methodology
}

\author{
Mathad R. Indudhar ${ }^{1}$, Nagaraj R. Banapurmath $\left.{ }^{2, *} \mathbb{(}\right)$, K. Govinda Rajulu ${ }^{3}$, Arun Y. Patil ${ }^{2} \mathbb{D}$, Syed Javed ${ }^{4}(\mathbb{D}$ \\ and T. M. Yunus Khan $4, * \mathbb{D}$ \\ 1 Research Scholar, JNTUA, Ananthapuramu 515002, India; indu.mr89@gmail.com \\ 2 Department of Mechanical Engineering, BVB College of Engineering and Technology, \\ KLE Technological University, Hubballi 580030, India; patilarun7@gmail.com \\ 3 Department of Mechanical Engineering, JNTUA College of Engineering, Ananthapuramu 515002, India; \\ govindjntu@gmail.com \\ 4 Department of Mechanical Engineering, College of Engineering, King Khalid University, \\ Abha 61421, Saudi Arabia; syedjavedme@gmail.com \\ * Correspondence: nrbanapurmath@gmail.com (N.R.B.); yunus.tatagar@gmail.com (T.M.Y.K.)
}

\section{check for}

updates

Citation: Indudhar, M.R.;

Banapurmath, N.R.; Rajulu, K.G.;

Patil, A.Y.; Javed, S.; Khan, T.M.Y

Optimization of Piston Grooves,

Bridges on Cylinder Head, and Inlet

Valve Masking of Home-Fueled

Diesel Engine by Response Surface

Methodology. Sustainability 2021, 13,

11411. https://doi.org/10.3390/

su132011411

Academic Editor: Talal Yusaf

Received: 8 August 2021

Accepted: 11 October 2021

Published: 15 October 2021

Publisher's Note: MDPI stays neutral with regard to jurisdictional claims in published maps and institutional affiliations.

Copyright: () 2021 by the authors. Licensee MDPI, Basel, Switzerland. This article is an open access article distributed under the terms and conditions of the Creative Commons Attribution (CC BY) license (https:// creativecommons.org/licenses/by/ $4.0 /$ )

\begin{abstract}
Naturally replenished biodiesel fuels are more precise in place of diesel engine applications as they have complying thermal properties, which are extensively used by various researchers. However, there is necessity to optimize their utility to meet stringent emission norms as per Bharat Stage VI (BS VI) and Euro 6. From the exhaustive survey on the studies, number of piston grooves (NG), number of grooves-n-bridges on cylinder head (Gr-Br), and inlet valve masking (IVM) using the response surface methodologies (RSM) technique have not been reported on the competence, emissions, and combustion attributes of diesel engines running on Honge oil methyl ester (HOME), hence this is an identified gap in literature. The present simulation work is for optimizing the performance and lessoning exhaust emitted from the diesel prime mover tested on non-conventional and petro fuels. Experimentation was carried out to inquest the competence, combustion, and emittance of a vertical cylinder, overhead valve, water cooling, open or induction swirl diesel engine running on HOME as the injecting fuel. The object of the present effort is to optimize competence of diesel engines via a statistics inquest called designs of experiments (DoE). To curtail the diverse variations to be experimented on, full factorial designs (FFDs) array was employed. The response surface methodologies (RSM)-based nonlinear or quadratic predictors establish the relation between the input parameters and proposed attributes. The RSM-based mathematical predictors are established to prognosticate the distinguished engine output attributes at $95 \%$ confidence interval. The response surface assay discovered that a combination of $2 \mathrm{~B} 3 \mathrm{G}$, 'IVM' of $90^{\circ}$, and 'NG' of six grooves yields highest brake thermal efficiency (BTE), lessoning smoke, carbon monoxide (CO), and hydrocarbon $(\mathrm{HC})$, but nitrogenous oxides $\left(\mathrm{NO}_{\mathrm{x}}\right)$ emissions increased slightly. Additionally, combustion attributes, such as Ignition delay (ID) and combustion duration (CD), were lessoned, but peak pressure (PP) and heat release rate (HRR) had a higher contrast to performance of HOME biodiesel in a conventional $\mathrm{CI}$ engine.
\end{abstract}

Keywords: Honge oil methyl ester; piston grooves; number of grooves-n-bridges on cylinder head; inlet valve masking; optimization; full factorials designs; response surface methodologies; regression; validity by international relevance

\section{Introduction}

Diesel powered CI engines have high part load thermo efficacy and hence are amply applied for power plant and automobile utilities. However, every country is becoming more and more aware of pollution caused due to their malodourous exhaust, vibration 
levels, noise, particulate matter, and smoke. Already stringent legislations are further updated regularly to control pollution and to avoid affecting the delicate ecosystem balance. NOx emission is especially weighed as a "strongest" greenhouse gas, having a deleterious effect on the ozone layer of the atmosphere. Hence, it is time to implement new optimization techniques that ameliorate the efficacy of diesel engines using its proven substitute biodiesel and in turn tackle environmental problems and ameliorate socio-economic tie ups. Agarwal et al. [1] showed that straight linseed oil posed operational and durability problems in the $\mathrm{CI}$ engine. These hindrances attribute to the polyunsaturated character of vegetable oils, i.e., they are less volatile and highly viscous. However, such problems were not encountered for in linseed oil methyl ester (LOME) biodiesel due to the transesterification process, which reduces its viscosity and thus rules out operating and longevity hurdles. Economic assay was also done in this inquest, and it was found that use of veggie oil and its BDF as an option for diesel costs almost the same as that of fossil diesel. Goldemberg and Coelhobn [2] proved that naturally replenished biofuels can be super temporal and are eco-friendly. Abuhabaya et al. [3] adopted response surface methodology (RSM), and a centralized complex rotating design (CCRD) matrix showed that the molarity ratio of methanol to raw sunflower oil and catalyst concentration had the most leveraging inputs in comparison to reaction time and reaction temperature, affecting the percentage conversion of fuel into biodiesel, which was validated by experimental testing. The model was fit and accordable to be put forth the actual linkages among vital variables, and the output with an acceptable determination fraction $(\mathrm{R} 2=0.8142)$, which directed that $81.42 \%$ of the variation in the outcome could be described by the second-order polynomial prediction, as revealed by assay of variance (ASOVA). Yashvir Singh et al. [4] optimized competence and emissions of cassia tora biodiesel, having five coded levels based on centralized complex rotatory design (CCRD) matrices. The best compound of input variants was recorded at $15^{\circ} \mathrm{bTDC}$ fuel injecting time, $221 \mathrm{bar}$ IOP of fuel, $40.1 \%$ mixture of cassia tora and diesel, and $47.3 \%$ engine loading, which emitted an outcome of highest BTE and lowest UBHC and NOx. Ganapathy, et al. [5] simulated the jatropha biodiesel performance using the Taguchi method and linear graph theory. The test trials layout of the engine was determined by a L16 orthogonal array. To maximize the competence, the signal noise ratio (SNR), related to higher-then-better (HTB) quality attributes, was utilized. The model correctly prognosticated Wiebe's heat releasing constants, the compression ratio, and duration of burning zone as the vital variables that influence the competence contrasted with other variables. Raheman and Phadatare [6] showed that, by blending Karanja esterified oil (B20 and B40) with diesel output responses, torque, brake power, and BTE increased and exhaust emissions decreased, thus controlling air pollution. Win et al. (2005) carried out a RSM fit statistics analysis for the input variables engine speed, static injection timing, and load as per the full factorial design array of $4 \times 4 \times 3$. They showed that two outputs, NOx and noise, have applicable good fittings, showing $R^{2}$ values of 0.963 and 0.971 , respectively, by ANOVA. Sufficiently better fitting was obtained for BSFC and smoke, with R2 valuated as 0.82 and 0.807 . The fitting of HC illustrates a poor fitting due to a very low value of $R^{2}$ 0.669 . Hirkude et al. [7] considered ratio of compression, blend, and load as input variables and predicted output variables by DoE based on RSM to optimize the competence of the diesel power unit with wasted fried oils methyl esters (WFOME) blending with fossil diesel. The developed models represent experimental data and are vital as values of $p$, which were less than 0.05 . The rightness of fit $\left(R^{2}\right)$ and the rightness of prognostication (Adjusting $R 2$ ) regression statistics are represented for all the outcomes. The predictors are accounted by value of Adjusted $\mathrm{R}^{2}$, and the model suits the data very well. The experimental validation of optimized inputs shows that measured responses were in good agreement with RSM values. The effect of speed, load, and blend ratio on the competence of a multi cylinder indirect injecting diesel power unit was investigated by Adam et al. (2015), using statistical tool, Box-Behnken design (BBD) based on RSM to predict and assess their net effects on the responses, such as torque, power, BSFC, and BTE. Blends of $5-20 \%$ volume of BDF (prepared from a mixture of palm and rubber seed oils) to diesel fuel were prepared. The 
load was found to be the most effective input, both individually and in combination, contrasted to variables blend and speed. A strong influence of speed over the outcomes was observed, except for torque, whereas its combined effect was not vital, except for BSFC and BTE. No paramount contribution was noticed for the blend over the outcomes, except for torque. However, the models established fitted the experimental results of all the outcomes investigated. Prasada Rao and Appa Rao [8] investigated indirect injection engine fueling with Mahua oil Methyl Ester (MOME), diesel, and methanol added blends, with predictor variables load and fuel, for nine output responses, such as EGT, BSFC, BTE, and emanations such as $\mathrm{UBHC}, \mathrm{CO}, \mathrm{CO}_{2}$, Oxygen $\mathrm{O}_{2}, \mathrm{NOx}$, and smoke. To find optimized responses, the set of experimental works were carried out using the DoE, as advised by Taguchi for lessoning cost and time. The optimized set of the fuel and load were found by Grey Relational Analysis (GRA), applying to the experimental data by transacting the multi outcome hurdle into the single outcome hurdle using Grey Relating Grades (GRG). The optimal combinations, $20 \mathrm{~kg}$ of loading and MOME $+3 \%$ Methanol, were found by calculating signal noise ratio for GRG. After GRA, the results were validated with the RSM, expediency approach was used, and the optimal combinations were found. The validation outcomes almost coincided with experimental outcomes. They concluded that, when MOME was blended with methanol, $\mathrm{CO}$ and $\mathrm{HC}$ emissions decreased because of the methanol's inherent oxygen content and hence reduced viscosity. GRA and expediency approach of the RSM was found to be the most effective and simple optimizing tool, and experiment outcomes almost coincided with the validated outcomes. For optimized engine variants of fuel blend, MOME $+3 \%$ Methanol, and loading of $20 \mathrm{~kg}$, high desirability was obtained, where the values of the EGT, BSFC, BTE, UBHC, $\mathrm{CO}, \mathrm{CO}_{2}, \mathrm{O}_{2}, \mathrm{NOx}$, and smoke intensity were found as $163.9^{\circ} \mathrm{C}, 0.3617 \mathrm{~kg} / \mathrm{kW}-\mathrm{h}, 26.341 \%, 3.82 \mathrm{ppm}, 0.0181 \%, 5.271 \%$, $20.983 \%, 230 \mathrm{ppm}$, and $36.555 \mathrm{HSU}$, respectively. Contrasting the validation result, there was an error of 0.0970 for the experimented result of loading. Berber [9] proposed RSM to find the performance of fuel flow in a DI diesel power unit by using diverse unique conditions (IOP, N, and throttle position). IOP was chosen as 150 bar for a turbo-charged and pre-combustion vestibule. A math model was used to prognosticate fuel flow competence, according to IOPs 100, 150, 200, and 250 bars and throttle positioning 50, 75, and $100 \%$. The optimized competence conditions for a needed fuel flow were obtained by using the response to surface methodologies with $3 \mathrm{D}$ graphing. The obtained polynomial predictions proved that the linear variation of engine speeds were most vital and affected the flow. A biodiesel fueled engine resulted in lessoned competence, increased fuel consumption, and UBHC and CO emitted with lessoned NOx levels [10]. The blend ratio and operating parameters were optimized using FFD for modelling and studying the experiments' data. Nayyar et al. [11] validated experimental data with forecasted values and discovered that models put forth were very easily used for adequacy checking. Combustion features were analyzed by many investigators using statistical tools. Hence, the use of RSM quadratic models has developed and explored the competence of double fuel engines, as shown in References [12-14], which analyzed the influence of EGR and IT on the competence and emanations of a diesel prime mover running on diesel blends. Using RSM, optimization was enacted through the expediency approach to lessen the smoke and NOx emanations levels with lessoned BSFC. The model building was done using the DoE-RSM combination, and an assay of multi linear regression math models were used to prognosticate the competence and emanations of diesel and $\mathrm{H} 2$-fueled engines at diverse loads. It was shown that outcomes obtained were at a $95 \%$ assurance level and hence were eloquent $[15,16]$. Further, the effect of injector variables and nozzle tip protuberance on the combustion attributes of two cylinders of natural aspiration diesel prime mover was explored using RSM statistic techniques. These variables got higher BTE and NOx with lesser BSFC, UBHC, and CO at optimum IT of $21^{\circ} \mathrm{bTDC}$ (before Top Dead Centre), IOP of $225 \mathrm{bar}$, and nozzle tip protuberance of $2.5 \mathrm{~mm}$ [17]. According to Reşitoğlu et al. [18], it is not possible to achieve emission norms by engine modifications only. Similarly, the numerical simulation results shows that the higher-pressure gasoline direct injecting improved smaller-scale turbulent 
intensity and evaporation of fuel, both at the same time. These duo effects were considered as the prime factors to enhance the flame propagation velocity, indicating new combustion ideas that were different from conventional SI combustion controlled by in-cylinder bulk flow, as reported by Kaminaga. et al. [19]. A set of laminar burning speeds with pressure, temperature, and equivalence ratio dependences were combined into a 3D-CFD calculation to compare the predicted displacements of flame front in an SI engine with that of the experiments. It was found that the reaction mechanism was very well validated in 1D-3D combustion calculations, as per the research by Ratnak. et al. [20].

\section{Present Work}

From the above literature survey, it is observed that research on the utility of biodiesels with design changes, NG, BG, and IVM, in diesel engines is rarely studied. Hence, these design changes need to be applied for detailed studies. Further RSM techniques have not been reported on the competence, emanations, or combustion attributes of diesel prime movers fueled with HOME with simultaneous design changes of NG, BG, and IVM in diesel engines. This work is an effort towards enhancing competence and curtailing exhaust emanations from diesel engines powered with renewable fuels. In addition, a statistical approach must be employed for modelling and optimization of engine variables and to ratify the valuable outcomes by the experiments inquest.

\section{Experimentation Particulars}

\subsection{Thermal Characters of Fuels Utilised}

Renewable Honge oil methyl esters (HOME) were derived from Honge vegetable oil through already improved and demonstrated technologies, called the simple alkali transesterification process, in which the Viscosity of HOME biodiesel obtained was $5.6 \mathrm{c}$. St at $40^{\circ} \mathrm{C}$, which is within the range of acceptance as diesel engine fuel, according to ASTM standards ( 1.9 to $6 \mathrm{c}$. St at $\left.40^{\circ} \mathrm{C}\right)$. Fuel properties in this inquest are tabulated in Table 1.

Table 1. Thermal characters of diesel, Honge oil, and its ester, HOME.

\begin{tabular}{|c|c|c|c|c|c|}
\hline S1. NoN & Properties & Diesel & Honge Oil & HOME & ASTM Standards \\
\hline 1 & Viscosity (c. St at $40^{\circ} \mathrm{C}$ ) & 4.59 & 56 & 5.6 & ASTMD445 \\
\hline 2 & Flash point $\left({ }^{\circ} \mathrm{C}\right)$ & 56 & 270 & 163 & ASTM D93 \\
\hline 3 & Calorific Value $(\mathrm{kJ} / \mathrm{kg})$ & 45,000 & 35,800 & 36,100 & ASTM D5865 \\
\hline 4 & Mass Density $\left(\mathrm{kg} / \mathrm{m}^{3}\right.$ at $\left.15^{\circ} \mathrm{C}\right)$ & 830 & 930 & 890 & ASTM D4052 \\
\hline 5 & Cetane Number & $45-55$ & 40 & $40-42$ & ASTM D613 \\
\hline 6 & Cloud Point $\left({ }^{\circ} \mathrm{C}\right)$ & 15 & 13 & & ASTM D2500 \\
\hline 7 & Pour Point $\left({ }^{\circ} \mathrm{C}\right)$ & 1 & -2 to -5 & & \\
\hline 8 & Carbon Residue (\%) & 0.1 & 0.66 & & ASTM D4530 \\
\hline 9 & Type of oil & Fossil fuel & Non edible & Non edible & \\
\hline
\end{tabular}

\subsection{Experimentation Methodologies}

The experiments were carried out on existing single cylinder four stroke CI prime movers to operate on HOME. Set up was interfaced with a data acquiring system with Engine soft as the software. Figure 1 shows the line diagram of the test unit and modification to run on selected fuel, and its specific features are given in Table 2. The prime mover was always run at a rated RPM of 1500. A piezoelectrical transducer for pressure (made by PCB Piezotronics, Model: HSM 111A22, with Resolution: $0.145 \mathrm{mV} / \mathrm{KPa}$ ) was fixed on the cylinder's head surface to record the cylinder gas pressure for a combustion inquest. Figure 2 shows IVM with a masking angle varying from $30^{\circ}, 60^{\circ}$, and $90^{\circ}$. The mask acts as a turbine blade and hence the inlet valve rotates along with its spring as inlet air flows into the cylinder. Thus, araldite was applied to the spring to fix it and avoid rotation of its inlet valve. Figure 3 shows altered cylinder heads with a diverse number of bridges-n-grooves. Figure 4 shows triangular-shaped grooves on the piston, and the number of grooves varies from 3 to 9 in steps of 3 . A five holes injector, with holes at a 
diameter of $0.3 \mathrm{~mm}$, was used, which was optimized in our previous work. The number of grooves made on the piston and cylinder head kept the same compression ratio and intensified the air swirl. An optimized IOP of 240 bar and injecting time fixed at $27^{\circ} \mathrm{bTDC}$ resulted in overall meliorated competence, while the compression ratio was kept constant at 17.5. The Hartridge smoke opacity meter was used to record the exhaust smoke intensity, which was a light extinction type working on the principle of a contrastive basis. The emitted levels of UBHC, CO, and NOx were measured by a DELTA $1600 \mathrm{~S}$ exhaust gas assayer. The exhaust gas assayer and smoke recorder, which were periodically calibrated, were switched on, and before measurements, they were allowed to attain a steady state. To assure high accuracy, readings were noted five times and were plotted after finding their average graphs.

\subsection{Uncertainties Estimated}

The experiment's inquest and data obtained may be uncertain and thus could creep into various processes and hinder the proper outcomes of the research. Errors, due to the use of many instruments and sensors, are bound to occur randomly from the changes, resulting from diverse trials and measurements. Systematic errors may be made constant by calibrating the instruments periodically. To minimize measuring error, five readings were taken, and the average values were considered for their results assay. Accuracy or correctness of recorded loading, engine speed, temperature, and fuel consumptions were $0.11,1.1,1.0$, and 0.12 , respectively. Uncertainties determined for $\mathrm{BTE} \%$, EGT ${ }^{\circ} \mathrm{C}$, and BSFC kg/kWh were $= \pm 1.2, \pm 3.1$, and \pm 1.1 , respectively. Similarly, uncertainties of outputs smoke HSU, UBHC ppm, CO $\%$, and NOx ppm were $\pm 5.25, \pm 2.35, \pm 2.6$, and \pm 2.35 , respectively.

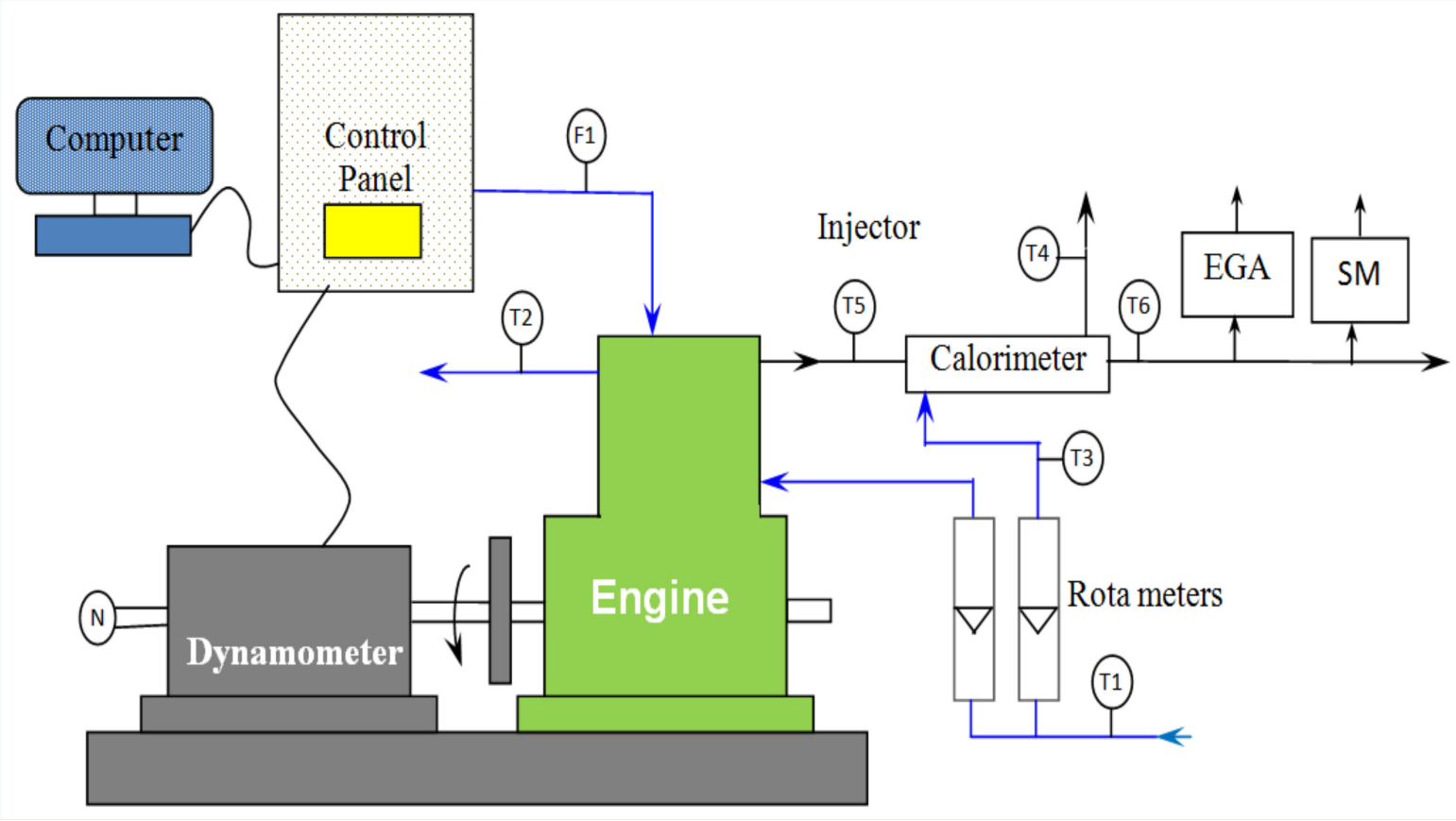

Figure 1. T1, T3 = Water inlet temperature, $\mathrm{T} 2=$ Engine water jacket outlet temperature, $\mathrm{T} 4=$ Calorimeter outlet temperature, T5 = Exhaust gas temperature (EGT) before calorimeter, T6 = EGT after calorimeter, F1= Fuel flow DP(differential pressure) unit, $\mathrm{PT}=$ Pressure transducer, $\mathrm{N}=\mathrm{RPM}$ encoder, EGA = Exhaust gas analyzer, $\mathrm{SM}=$ Smoke meter. 
Table 2. Diesel engine specifications.

\begin{tabular}{ccc}
\hline S1. No. & Parameters & Specifications \\
\hline 1 & Engine type & TV1 (Kirloskar make) \\
2 & Software interfaced & Engine soft \\
3 & Injector opening pressure & 200 to $225 \mathrm{bar}$ \\
4 & Static injecting time & $23^{\circ} \mathrm{bTDC}$ \\
5 & Governor type & Centrifugal type Mechanical \\
6 & Number of cylinders & Single cylinder \\
7 & Number of strokes & 4 strokes \\
8 & Fuel oil & Diesel \\
9 & Rated power & $5.2 \mathrm{~kW}$ at $1500 \mathrm{rpm}$ \\
10 & Cylinder diameter (Bore) & $0.0875 \mathrm{~m}$ \\
11 & Stroke length & $0.11 \mathrm{~m}$ \\
12 & Ratio of compression & $17.5: 1$ \\
\hline
\end{tabular}
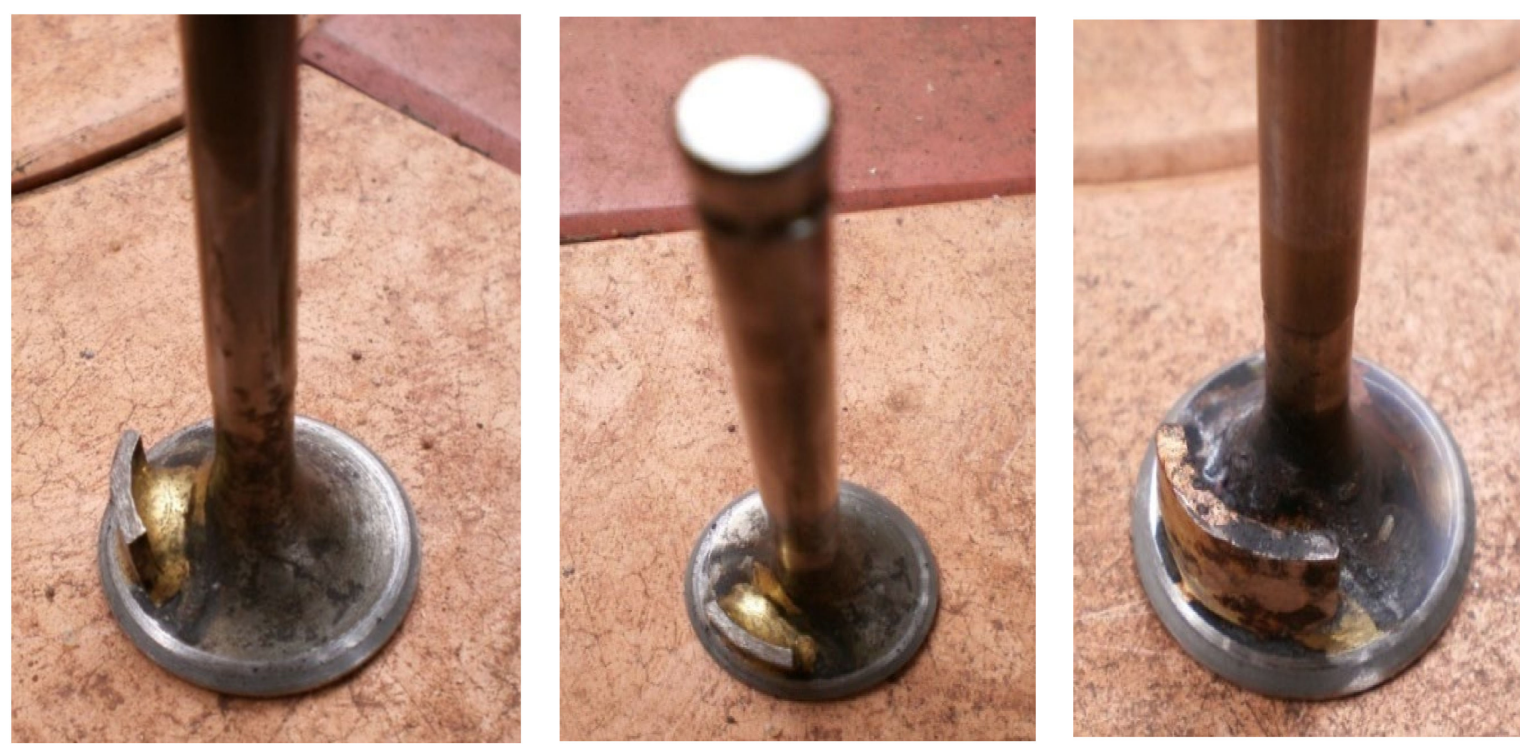

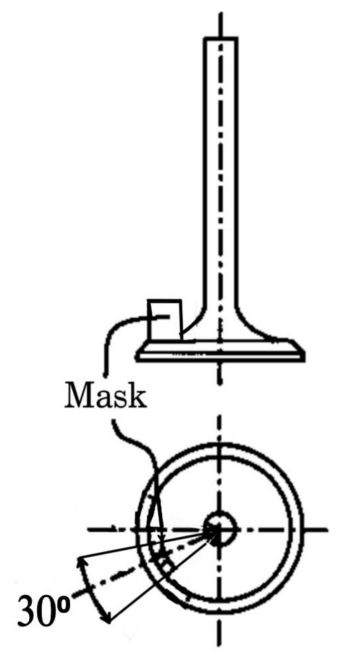

(a)

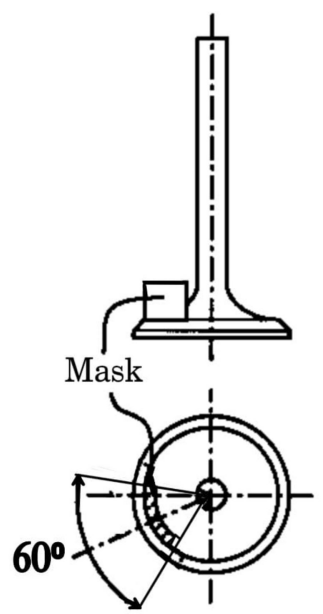

(b)

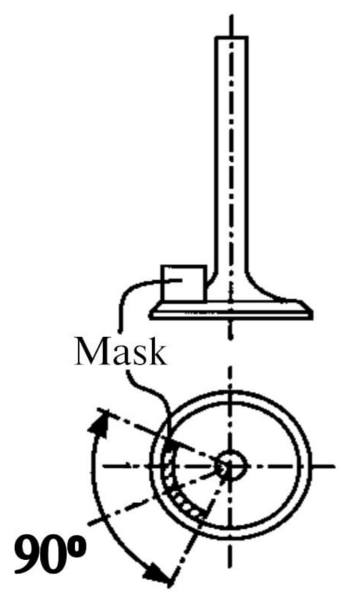

(c)

Figure 2. Masking inlet valve with different mask angles ${ }^{\circ}$. (a) $30^{\circ}$; (b) $60^{\circ}$; (c) $90^{\circ}$. 

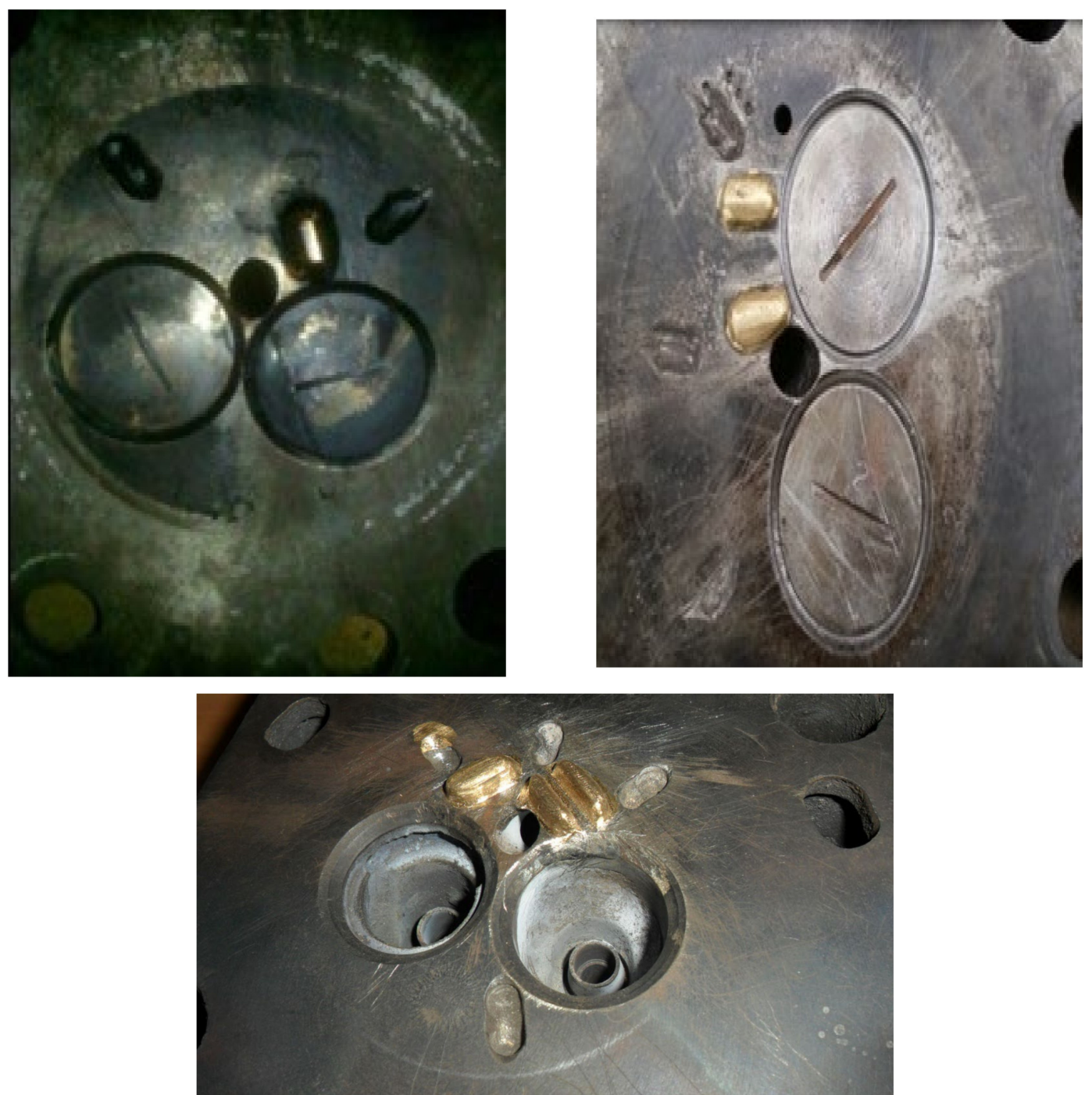

Figure 3. Cylinder heads modified with diverse numbers of bridges-n-grooves, all having the same compression ratio.

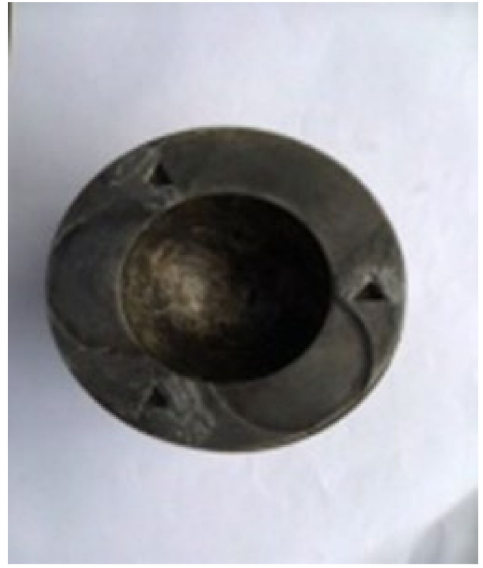

(a)

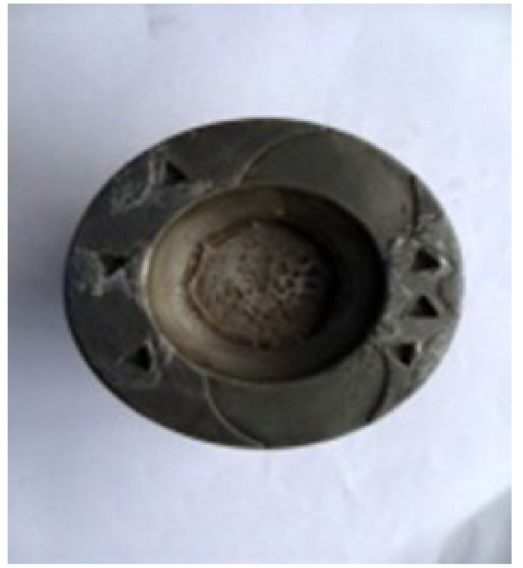

(b)

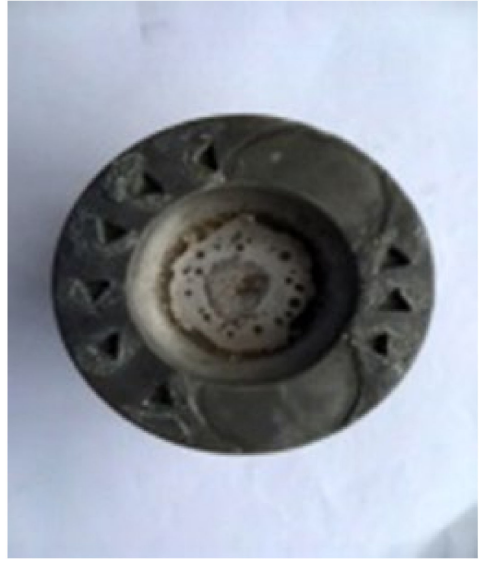

(c)

Figure 4. Piston grooves: (a) 3 grooves (b) 6 grooves, and (c) 9 grooves. 


\subsection{Design of Experiments and Experimentation}

The designs of experiments (DoE) gave us the outcomes of several possible variations that coincidentally had fewer numbers of experimental inquests to be conducted within the minimum time frame and lessoned material consumptions.

The entire process of sampling was well extracted based on the earlier iterations on the experimental work. Further care was taken to arrive at the data points after several cases of dry runs. The exhaustive study used predicted the results near to the accuracy study, with a $90-95 \%$ confidence level.

Based on many facts and their levels, an appropriate DoE was selected [3,21-23]. In this work, three input variants, namely number of piston grooves, inlet valve masking, and number of grooves-n-bridges on cylinder heads, were considered as predictor variables or regressors, selecting their range based on previous works. Such input variants chosen for the inquest with levels are shown in Table 3, and the designs of the experimentation plan is presented in Table 4 . The readings were recorded, and competence, emanations, and combustion attributes, i.e., BTE, smoke, UBHC, CO, NOx, PP, ID, CD, and HRR, were determined. Additionally, emissions attributes were obtained using calibration of devices and are presented in Table 5.

Table 3. Notified engine predictor variables and levels.

\begin{tabular}{ccccc}
\hline Variables & Notation and Units & \multicolumn{2}{c}{ Levels } \\
\hline Number of grooves on piston & G or A, Nr & 3 & 6 & 9 \\
Inlet valve masking & M or B, Degrees & 30 & 60 & 90 \\
Grooves and Bridges on Cylinder head & Br-Gr or C, Nr & 3 & 5 & 7 \\
\hline
\end{tabular}

Table 4. Matrix of experimental design plan and measured values of responses.

\begin{tabular}{|c|c|c|c|c|c|c|c|c|c|c|c|c|}
\hline \multirow{3}{*}{ Trial No. } & \multicolumn{3}{|c|}{ Settings of Parameters } & \multicolumn{9}{|c|}{ Responses Characteristics (80\% Load) } \\
\hline & \multirow{2}{*}{ No. of Grove } & \multirow{2}{*}{$\frac{\text { Masking }}{\text { (Degree) }}$} & \multirow{2}{*}{ BR-GR } & BTE & Smoke & $\mathrm{HC}$ & $\mathrm{CO}$ & $\mathrm{NO}_{\mathbf{x}}$ & Pmax & ID & CD & HRR \\
\hline & & & & $(\%)$ & (HSU) & (ppm) & $(\%)$ & (ppm) & (Bar) & ( $\left.{ }^{\circ} \mathrm{CA}\right)$ & $\left({ }^{\circ} \mathrm{CA}\right)$ & $\left(\mathrm{J} /{ }^{\circ} \mathrm{CA}\right)$ \\
\hline 1 & 3 & 30 & $1 \mathrm{~B} 2 \mathrm{G}$ & 23.5 & 67 & 60 & 0.35 & 730 & 55 & 20 & 33 & 60 \\
\hline 2 & 3 & 30 & 2B3G & 25.5 & 58 & 49 & 0.31 & 750 & 60 & 18 & 31 & 63 \\
\hline 3 & 3 & 30 & 3B4G & 24.5 & 62 & 57 & 0.33 & 740 & 58 & 19 & 32 & 62 \\
\hline 4 & 3 & 60 & $1 \mathrm{~B} 2 \mathrm{G}$ & 24.15 & 65 & 58 & 0.33 & 740 & 57 & 19 & 32 & 62 \\
\hline 5 & 3 & 60 & $2 \mathrm{~B} 3 \mathrm{G}$ & 26.25 & 54 & 47 & 0.29 & 760 & 62 & 17 & 30 & 65 \\
\hline 6 & 3 & 60 & $3 B 4 G$ & 25.20 & 60 & 55 & 0.31 & 750 & 60 & 18 & 31 & 64 \\
\hline 7 & 3 & 90 & $1 \mathrm{~B} 2 \mathrm{G}$ & 24.85 & 63 & 56 & 0.31 & 760 & 60 & 17 & 31 & 64 \\
\hline 8 & 3 & 90 & $2 B 3 G$ & 27.95 & 52 & 45 & 0.27 & 780 & 65 & 15 & 29 & 67 \\
\hline 9 & 3 & 90 & $3 B 4 G$ & 25.75 & 58 & 53 & 0.29 & 770 & 63 & 16 & 30 & 66 \\
\hline 10 & 6 & 30 & $1 \mathrm{~B} 2 \mathrm{G}$ & 25.45 & 61 & 54 & 0.3 & 790 & 61 & 16 & 30 & 65 \\
\hline 11 & 6 & 30 & $2 \mathrm{~B} 3 \mathrm{G}$ & 28.53 & 50 & 43 & 0.26 & 810 & 66 & 14 & 28 & 69 \\
\hline 12 & 6 & 30 & $3 B 4 G$ & 26.25 & 56 & 51 & 0.27 & 800 & 64 & 15 & 29 & 67 \\
\hline 13 & 6 & 60 & $1 \mathrm{~B} 2 \mathrm{G}$ & 26.05 & 59 & 52 & 0.28 & 810 & 63 & 15 & 28 & 67 \\
\hline 14 & 6 & 60 & $2 \mathrm{~B} 3 \mathrm{G}$ & 29.15 & 49 & 41 & 0.24 & 830 & 68 & 13 & 26 & 71 \\
\hline 15 & 6 & 60 & $3 \mathrm{~B} 4 \mathrm{G}$ & 27.15 & 57 & 49 & 0.25 & 820 & 66 & 14 & 27 & 69 \\
\hline 16 & 6 & 90 & $1 \mathrm{~B} 2 \mathrm{G}$ & 28.55 & 57 & 50 & 0.26 & 840 & 65 & 14 & 26 & 69 \\
\hline 17 & 6 & 90 & $2 \mathrm{~B} 3 \mathrm{G}$ & 31.55 & 47 & 39 & 0.22 & 860 & 70 & 12 & 24 & 73 \\
\hline 18 & 6 & 90 & $3 B 4 G$ & 28.15 & 55 & 47 & 0.24 & 850 & 68 & 13 & 25 & 71 \\
\hline 19 & 9 & 30 & $1 \mathrm{~B} 2 \mathrm{G}$ & 24.47 & 64 & 57 & 0.33 & 760 & 58 & 18 & 31 & 62 \\
\hline 20 & 9 & 30 & $2 \mathrm{~B} 3 \mathrm{G}$ & 26.52 & 54 & 46 & 0.29 & 780 & 63 & 16 & 29 & 66 \\
\hline 21 & 9 & 30 & $3 B 4 G$ & 25.37 & 59 & 54 & 0.30 & 770 & 61 & 17 & 30 & 64 \\
\hline 22 & 9 & 60 & $1 \mathrm{~B} 2 \mathrm{G}$ & 25.10 & 62 & 55 & 0.31 & 775 & 60 & 17 & 30 & 65 \\
\hline 23 & 9 & 60 & $2 \mathrm{~B} 3 \mathrm{G}$ & 27.20 & 52 & 44 & 0.27 & 795 & 65 & 15 & 28 & 68 \\
\hline 24 & 9 & 60 & $3 \mathrm{~B} 4 \mathrm{G}$ & 26.17 & 59 & 52 & 0.28 & 785 & 63 & 16 & 29 & 66 \\
\hline 25 & 9 & 90 & $1 \mathrm{~B} 2 \mathrm{G}$ & 25.70 & 60 & 53 & 0.29 & 800 & 62 & 15 & 28 & 67 \\
\hline 26 & 9 & 90 & 2B3G & 30.25 & 50 & 50 & 0.25 & 820 & 68 & 13 & 26 & 70 \\
\hline 27 & 9 & 90 & $3 B 4 G$ & 27.95 & 57 & 51 & 0.27 & 810 & 66 & 14 & 27 & 69 \\
\hline
\end{tabular}


Table 5. RSM fitted values of the competence, combustion, and emanation attributes.

\begin{tabular}{|c|c|c|c|c|c|c|c|c|c|c|c|c|}
\hline \multirow{3}{*}{ Trial No. } & \multicolumn{3}{|c|}{ Parameter Settings } & \multicolumn{9}{|c|}{ Fitted Responses (80\% Load) } \\
\hline & \multirow{2}{*}{ No. of Grove } & \multirow{2}{*}{$\frac{\text { Masking }}{\text { (Degree) }}$} & \multirow{2}{*}{ BR-GR } & BTE & Smoke & $\mathrm{HC}$ & $\mathrm{CO}$ & NOx & Pmax & ID & CD & HRR \\
\hline & & & & $(\%)$ & (HSU) & (ppm) & $(\%)$ & (ppm) & (Bar) & $\left({ }^{\circ} \mathrm{CA}\right)$ & $\left({ }^{\circ} \mathrm{CA}\right)$ & $\left(\mathrm{J} /{ }^{\circ} \mathrm{CA}\right)$ \\
\hline 1 & 3 & 30 & $1 B-2 G$ & 23.5215 & 67.3796 & 60.2500 & 0.351574 & 717.5 & 55.1574 & 19.8889 & 33.1944 & 59.8611 \\
\hline 2 & 3 & 30 & $2 B-3 G$ & 25.5694 & 56.4074 & 49.9722 & 0.311574 & 747.5 & 60.1019 & 17.8889 & 33.1944 & 63.3889 \\
\hline 3 & 3 & 30 & $3 B-4 G$ & 24.3757 & 61.9907 & 57.0278 & 0.327130 & 737.5 & 57.9352 & 18.8889 & 33.1944 & 61.9167 \\
\hline 4 & 3 & 60 & $1 B-2 G$ & 24.1174 & 65.0741 & 57.4167 & 0.329074 & 740.0 & 57.1574 & 18.8889 & 32.1111 & 61.8056 \\
\hline 5 & 3 & 60 & $2 B-3 G$ & 26.2528 & 54.5185 & 47.2222 & 0.290741 & 760.0 & 62.1852 & 16.8889 & 30.1111 & 65.3333 \\
\hline 6 & 3 & 60 & $3 B-4 G$ & 25.1465 & 60.5185 & 54.3611 & 0.307963 & 750.0 & 60.1019 & 17.8889 & 31.1111 & 63.8611 \\
\hline 7 & 3 & 90 & $1 B-2 G$ & 24.7465 & 62.3241 & 55.5833 & 0.308796 & 762.5 & 59.7130 & 17.2222 & 30.6944 & 63.7500 \\
\hline 8 & 3 & 90 & $2 B-3 G$ & 27.9694 & 52.1852 & 45.4722 & 0.272130 & 782.5 & 64.8241 & 15.2222 & 28.6944 & 67.2778 \\
\hline 9 & 3 & 90 & $3 B-4 G$ & 25.9507 & 58.6019 & 52.6944 & 0.291019 & 772.5 & 62.8241 & 16.2222 & 29.6944 & 65.8056 \\
\hline 10 & 6 & 30 & $1 B-2 G$ & 25.4458 & 61.3796 & 53.4167 & 0.300185 & 795.0 & 60.8241 & 16.2222 & 29.4444 & 65.1111 \\
\hline 11 & 6 & 30 & $2 B-3 G$ & 28.3167 & 50.7407 & 43.2222 & 0.258519 & 815.0 & 65.8519 & 14.2222 & 27.4444 & 68.5556 \\
\hline 12 & 6 & 30 & $3 B-4 G$ & 26.3458 & 56.6574 & 50.3611 & 0.272407 & 805.0 & 63.7685 & 15.2222 & 28.4444 & 67.0000 \\
\hline 13 & 6 & 60 & $1 B-2 G$ & 26.0667 & 59.4074 & 51.3333 & 0.278519 & 810.0 & 62.7407 & 15.2222 & 28.1111 & 67.2222 \\
\hline 14 & 6 & 60 & $2 B-3 G$ & 28.8250 & 49.1852 & 41.2222 & 0.238519 & 830.0 & 67.8519 & 13.2222 & 26.1111 & 70.6667 \\
\hline 15 & 6 & 60 & $3 B-4 G$ & 27.1417 & 55.5185 & 48.4444 & 0.254074 & 820.0 & 65.8519 & 14.2222 & 27.1111 & 69.1111 \\
\hline 16 & 6 & 90 & $1 B-2 G$ & 28.7208 & 56.9907 & 50.2500 & 0.259074 & 835.0 & 65.2130 & 13.5556 & 26.4444 & 69.3333 \\
\hline 17 & 6 & 90 & $2 B-3 G$ & 31.3679 & 47.1852 & 40.2222 & 0.220741 & 855.0 & 71.4074 & 11.5556 & 24.4444 & 72.7778 \\
\hline 18 & 6 & 90 & $3 B-4 G$ & 27.9708 & 53.9352 & 47.5278 & 0.237963 & 845.0 & 68.4907 & 12.5556 & 25.4444 & 71.2222 \\
\hline 19 & 9 & 30 & $1 B-2 G$ & 24.4118 & 63.6019 & 56.5833 & 0.331019 & 757.5 & 58.0463 & 17.8889 & 31.3611 & 62.3611 \\
\hline 20 & 9 & 30 & $2 B-3 G$ & 26.5056 & 53.2963 & 46.4722 & 0.287685 & 777.5 & 63.1574 & 15.8889 & 29.3611 & 65.7222 \\
\hline 21 & 9 & 30 & $3 B-4 G$ & 25.3576 & 59.5463 & 53.6944 & 0.299907 & 767.5 & 61.1574 & 16.8889 & 30.3611 & 64.0833 \\
\hline 22 & 9 & 60 & $1 B-2 G$ & 25.0576 & 61.9630 & 55.2500 & 0.310185 & 775.0 & 59.8796 & 16.8889 & 29.7778 & 64.6389 \\
\hline 23 & 9 & 60 & $2 B-3 G$ & 27.2389 & 52.0741 & 45.2222 & 0.268519 & 795.0 & 65.0741 & 14.8889 & 27.7778 & 68.0000 \\
\hline 24 & 9 & 60 & $3 B-4 G$ & 26.1785 & 58.7407 & 52.5278 & 0.282407 & 785.0 & 63.1574 & 15.8889 & 28.7778 & 66.3611 \\
\hline 25 & 9 & 90 & $1 B-2 G$ & 25.7368 & 59.8796 & 54.9167 & 0.291574 & 802.5 & 62.2685 & 15.2222 & 27.8611 & 66.9167 \\
\hline 26 & 9 & 90 & $2 B-3 G$ & 30.1056 & 50.4074 & 44.9722 & 0.251574 & 822.5 & 67.5463 & 13.2222 & 25.8611 & 70.2778 \\
\hline 27 & 9 & 90 & $3 B-4 G$ & 27.0326 & 57.4907 & 52.3611 & 0.267130 & 812.5 & 65.7130 & 14 & 26.8611 & 68.6389 \\
\hline
\end{tabular}

\subsection{Response Surface Modelling and Assay}

RSM is extensively applied to problems in which numerous inputs with different levels potentially influence the competence of responses or the quality attributes of the process. The results are shown in the form of a surface of responses between input parameters. Hence, every point is a predicted and optimized useful result, maximizing or minimizing a response. Thus, any desirable point can be selected, its operating conditions are fixed accordingly, and an experiment can be conducted. The mathematic modeling for outcomes is fixed with correlation among input predictors. The quadratic polynomial predictor based on RSM is given by [24].

$$
Z=C_{o}+\sum_{i=1}^{k} C_{i} X_{i}+\sum c_{i i} X_{i}^{2}+\sum_{i \triangleleft j=2} c_{i j} X_{i} X_{j}
$$

Equation (1) is the response surface $Z$ that accounts linearity, interactions, and curvylinear terms, where

$c_{\mathrm{O}}=$ constant coefficient,

$c_{i}^{\prime} \mathrm{s}=$ coefficients for all linearity terms,

$c_{i i}{ }^{\prime} \mathrm{s}=$ coefficients for quadratic terms,

$c_{i j}{ }^{\prime} \mathrm{s}=$ coefficients for interactions terms.

The regression predictors and regressing coefficients are obtained according to the literature given in Reference [19]:

$$
c=\left(X^{T} X\right)^{-1} X^{T} Z
$$

where $C=$ matrix for input variant estimations;

$X=$ calculations matrix, which includes linear, interaction, and quadratic terms;

$X^{T}=$ transposing of matrix $X$ and $Z$ is the matrix of the outcome attribute. 
The current work can reach for higher order polynomials, at least mathematically; however, the interpretation of higher order modelling is complex. There is always a higher risk of introducing over-fitting of the model, which might result in bad predictions. On the other hand, more terms could result in multi-collinearity and ill-conditioning of $\left(X^{\prime} X\right)$, which can become an issue as the second-degree terms are the square or product of the first-degree terms and so forth.

The established predicting models are obtained through multiple regressing assays using the Design-Expert11 software program. The regression equations in terms of uncoded variables are:

$$
\begin{aligned}
& \mathrm{BTE}=9.11701+2.10081 \times \mathrm{A}+0.01299 \times \mathrm{B}+4.21042 \times \mathrm{C}-0.16435 \times \mathrm{A}^{2}+0.00002 \times \mathrm{B}^{2} \\
& -0.40521 \times \mathrm{C}^{2}+0.00028 \times \mathrm{A} \times \mathrm{B}+0.00382 \times \mathrm{A} \times \mathrm{C}+0.006764444 \times \mathrm{B} \times \mathrm{C} \\
& \mathrm{SMOKE}=132.42-6.389 \times \mathrm{A}-0.087 \times \mathrm{B}-22.417 \times \mathrm{C}+0.457 \times \mathrm{A}^{2}-2.069 \times \mathrm{C}^{2}+0.004 \times \mathrm{A} \times \mathrm{B} \\
& +0.056 \times \mathrm{A} \times \mathrm{C}+0.007 \times \mathrm{B} \times \mathrm{C}
\end{aligned}
$$

Smoke considerably decreased due to the linear and quadratic effect of the $C$ configuration due to a large negative co-efficient. Similarly, the linear and quadratic effect of A influences smoke formation. Piston grooves and grooves-n-bridges on cylinder heads enhance the rate of swirl and hence the rate of combustion, resulting in less smoke. Similarly, the linear effect of masking $B$ and the interactive effect of $B$ and $C$ have less effect on smoke formation and others have negligible effect.

$$
\begin{aligned}
\mathrm{HC}=129.833-\quad 7.569 \times \mathrm{A}- & 0.177 \times \mathrm{B}-22.556 \times \mathrm{C}+0.556 \times \mathrm{A} 2+0.001 \times \mathrm{B}^{2}+2.167 \times \mathrm{C}^{2} \\
& +0.0008 \times \mathrm{A} \times \mathrm{B}+0.014 \times \mathrm{A} \times \mathrm{C}+0.001 \times \mathrm{B} \times \mathrm{C}
\end{aligned}
$$

$\mathrm{HC}$ considerably decreases due to the linear and quadratic effect of $C$ configuration due to a large negative co-efficient. Similarly, the linear and quadratic effect of A influences smoke formation. Piston grooves and grooves-n-bridges on cylinder heads enhance the rate of swirl and hence the rate of combustion, resulting in less HC. Similarly, the linear effect of masking B has a considerable effect because it meliorates swirl, decreasing HC formation and offsetting its associated effect of decrease in volumetric efficiency.

$$
\begin{aligned}
& \mathrm{CO}=0.674907-0.057685 \times \mathrm{A}-0.000972 \times \mathrm{B}-0.075556 \times \mathrm{C}-0.04568 \times \mathrm{A}^{2}+0.000001 \times \mathrm{B}^{2} \\
& +0.006944 \times \mathrm{C}^{2}+0.000009 \times \mathrm{A} \times \mathrm{B}-0.000278 \times \mathrm{A} \times \mathrm{C}+0.000028 \times \mathrm{B} \times \mathrm{C} \\
& \mathrm{NOx}=468.750+74.167 \times \mathrm{A}-0.167 \times \mathrm{B}+40.0008 \times \mathrm{C}-5.833 \times \mathrm{A}^{2}+0.006 \times \mathrm{B}^{2}-3.750 \times \mathrm{C}^{2} \\
& +0.0028 \times \mathrm{A} \times \mathrm{B} \\
& \operatorname{Pmax}=19.0185+6.0972 \times A+0.0375 \times B+9.500 \times C-0.4691 \times A^{2}+0.0003 \times B^{2}-0.8889 \times C^{2} \\
& -0.0009 \times \mathrm{A} \times \mathrm{B}+0.0139 \times \mathrm{A} \times \mathrm{C}+0.0014 \times \mathrm{B} \times \mathrm{C}
\end{aligned}
$$


For all linear coefficients significantly increasing the response, their quadratic effect tends to decrease the response with a negligible interactive effect.

$$
\text { ID }=37.8472-3.8889 \times \mathrm{A}+4.00 \times \mathrm{C}+0.0963 \times \mathrm{A}^{2}-0.0004 \times \mathrm{B}^{2}+0.3750 \times \mathrm{C}^{2}
$$

Linear coefficients and quadratic coefficients increase this response.

$$
\begin{array}{cc}
\mathrm{CD}=51.7361- & 4.00 \times \mathrm{A}-0.0111 \times \mathrm{B}-4.0000 \times \mathrm{C}+0.3148 \times \mathrm{A}^{2}-0.0002 \times \mathrm{B}^{2}-0.3750 \times \mathrm{C}^{2} \\
& -0.0028 \times \mathrm{A} \times \mathrm{B}
\end{array}
$$

Linear coefficient of A decreases this response, but its quadratic coefficient increases the response. Quadratic coefficient of $C$ decreases the response and has a considerable interactive effect on A and B.

$$
\begin{gathered}
\mathrm{HRR}=30.0417+5.7361 \times \mathrm{A}+0.0593 \times \mathrm{B}+6.8056 \times \mathrm{C}-0.4444 \times \mathrm{A}^{2}-0.6250 * \mathrm{C}^{2} \\
+0.0019 \times \mathrm{B} \times \mathrm{C}
\end{gathered}
$$

For HRR, all linear coefficients significantly increase the response, while quadratic coefficients of $A$ and $C$ decrease the response and have negligible interactive effects. NOTE: It is to be observed that interactions were particularly important for BTE and CD. They indirectly decreased emissions where BTE was in \%, smoke in HSU, HC in ppm, CO in \%, NOx in ppm, ID in ${ }^{\circ} \mathrm{CA}, \mathrm{CD}$ in ${ }^{\circ} \mathrm{CA}$, Pmax in bar, and HRR in $\mathrm{J} /{ }^{\circ} \mathrm{CA}$.

The paramount parameter tests were: (1) Z-tests; (2) $t$-tests; $\left({ }^{*} 3\right) \mathrm{X}^{2}$-tests, and (4) F-tests, which were based on the normality assumption, i.e., the source for data taken had normal distribution. The Fisher (F)-test [24] was used to check the sufficiency of the RSM fittings-based modellings and was found to be adequately applicable at $95 \%$ assurance level.

The contrasted prognosticated and experimented values of competence attributes can be shown by graphs which were drawn taking two variables at a time, while keeping the third variable at the central level.

The response surface model accuracy was given by calculating the error of prognostication, i.e.:

$$
\Delta=\frac{100}{n} \sum_{i=1}^{n}\left|\frac{y_{i, \text { exp } t}-y_{i, \text { pred }}}{y_{i, \text { pred }}}\right|
$$

where, yi, except design of experiments (DoE) value of competence, attributes correspond to the $i$ th trial. $y i$, predicted: RSM predicted value of competence attribute, corresponding to $i$ th trial $n$ : number of trials in FFD.

Equations (3)-(11) are used to test the accuracy of the predictors, taking the experimented data set in FFDs. The percentages predicting errors were found to be $0.58,-0.392$, $-3.038,-0.3356,0.5847,-1.97,3.845,-1.818$, and 0.3053 for the BTE, smoke, HC, CO, NOx, Pmax, ID, CD, and HRR model, respectively. As the percentage of predicting errors are small, the RSM predicted values may be considered for implementation by corresponding design change and anticipating better results. However, it can be noted that percentage errors are more for HC and ID, as reported in literature by [4,6,23]. Yashvir Singh et al. [4] gave percentage errors for BTE, $\mathrm{HC}$, and NOx as 3.97, 4.65, and 2.67, respectively.

Therefore, Equations (3)-(11) are used to prognosticate the required attribute by substitution of the values of piston grooves, inlet valve masking, and number of grooves$\mathrm{n}$-bridges on cylinder heads within the ranges of the variants notified. The impact of notified input variables on competence, emissions, and combustion attributes are shown in Figures 5-13. These contours were obtained, taking two variables at a time while keeping the third variable at the central level. 

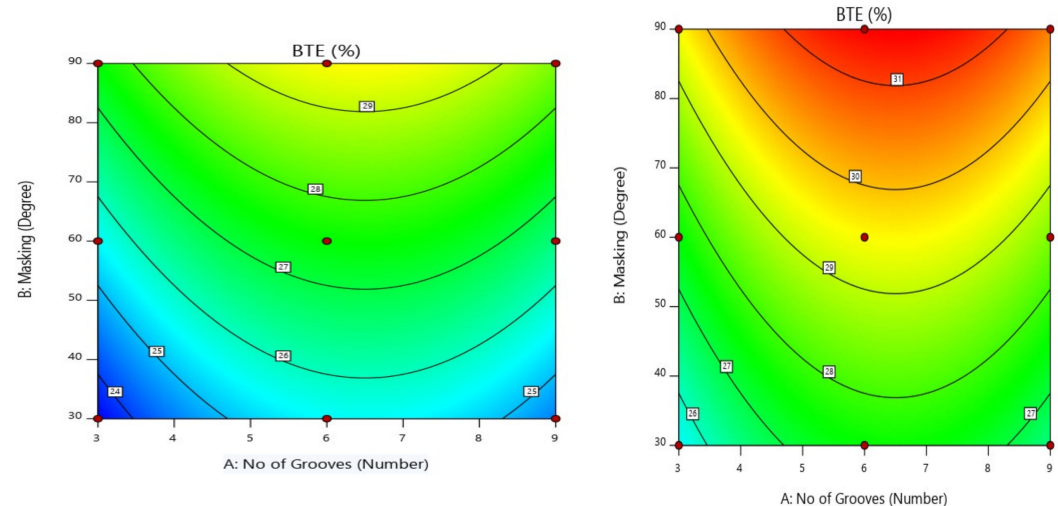

2B $3 G$

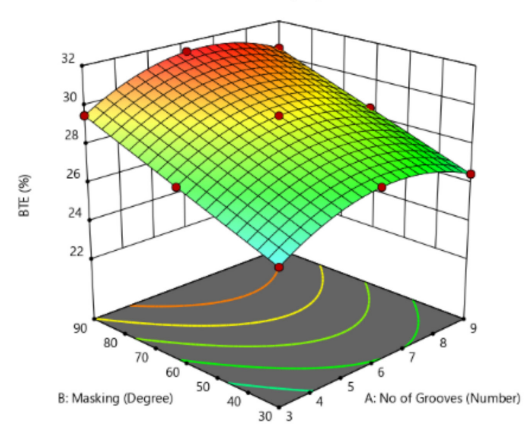

Figure 5. Effect of the 'IVM' and 'NG' on BTE.

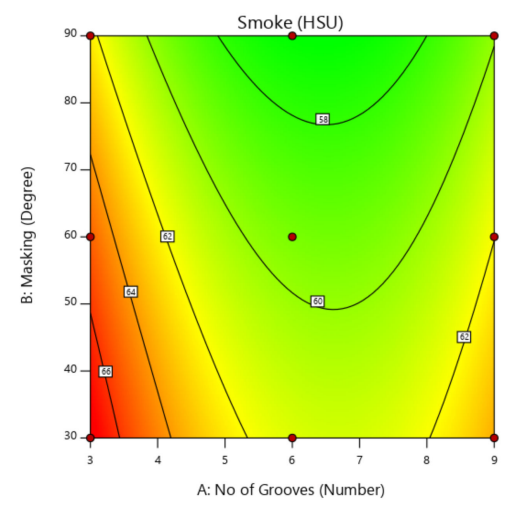

1B 2G

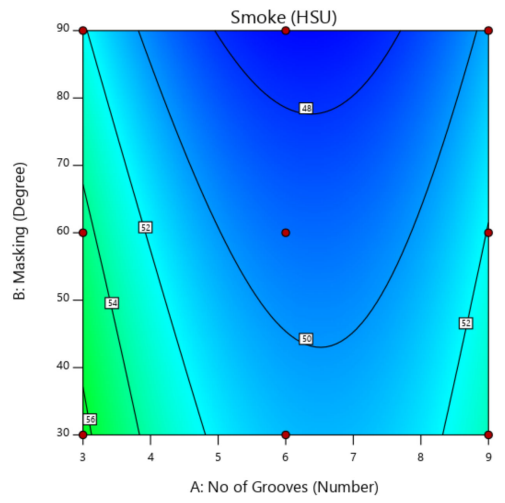

2B 3G

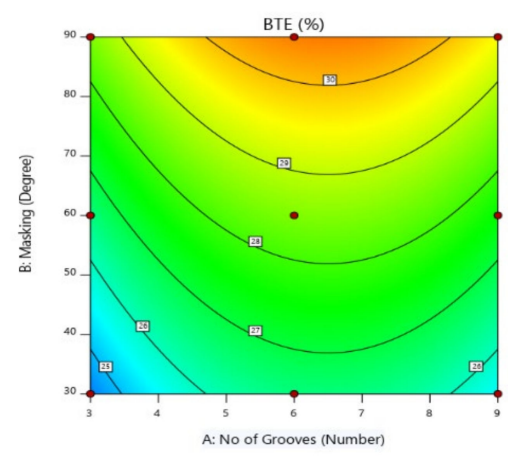

3B 4G

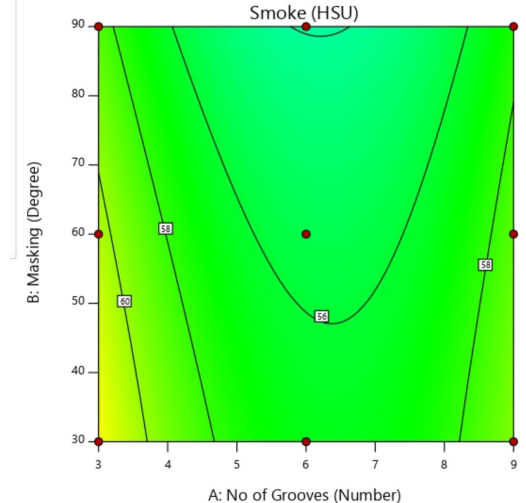

3B $4 \mathrm{G}$

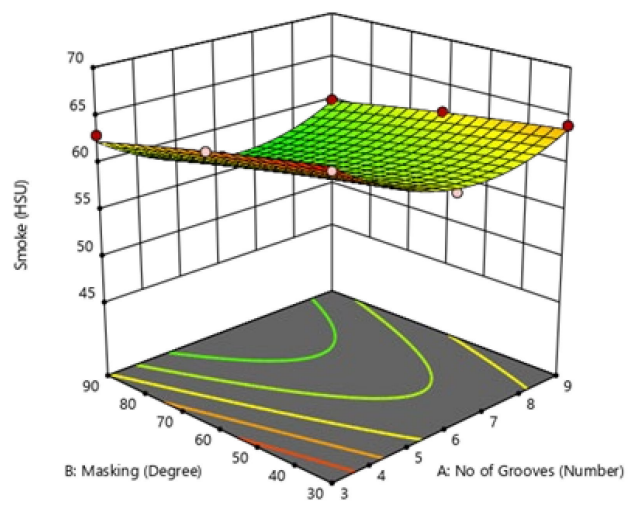

Figure 6. Effect of the 'IVM' and 'NG' on smoke emission. 


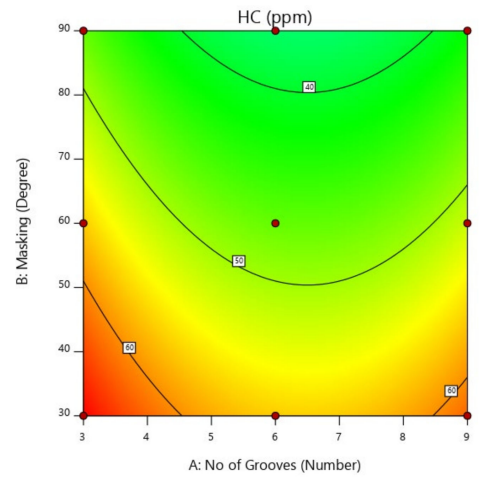

1B 2G

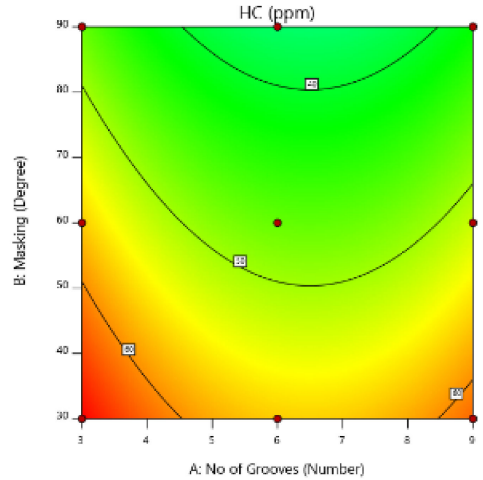

2B 3G

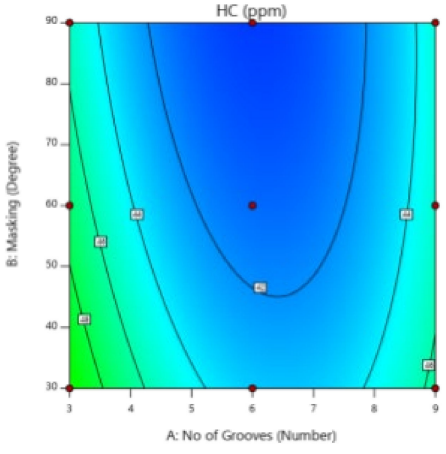

3B 4G

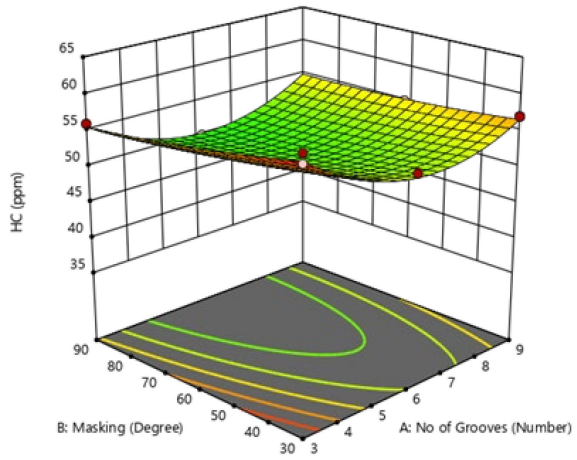

Figure 7. Effect of the 'IVM' and 'NG' on HC emission.

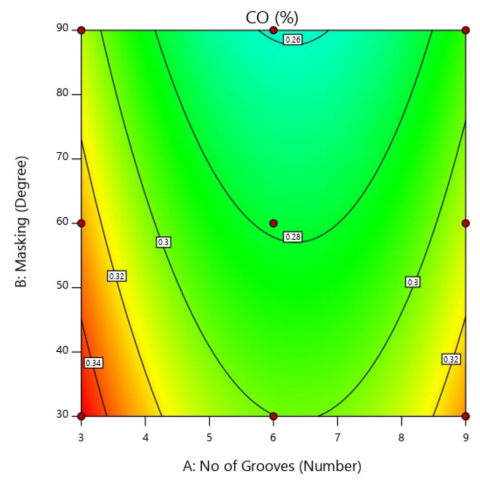

1B 2G

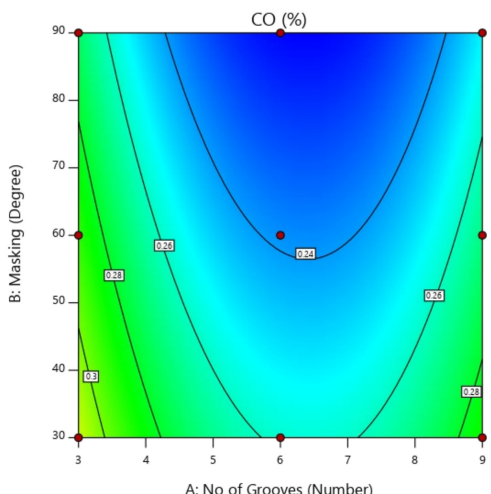

2B 3G

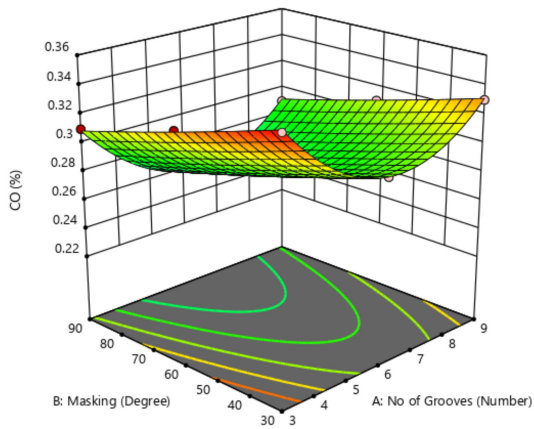

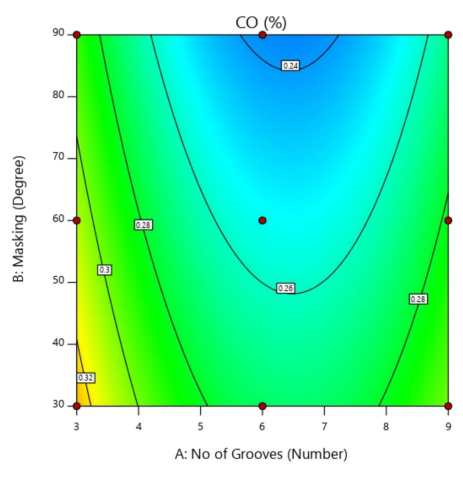

3B 4G

Figure 8. Effect of the 'IVM' and 'NG' on $\mathrm{CO}$ emission. 


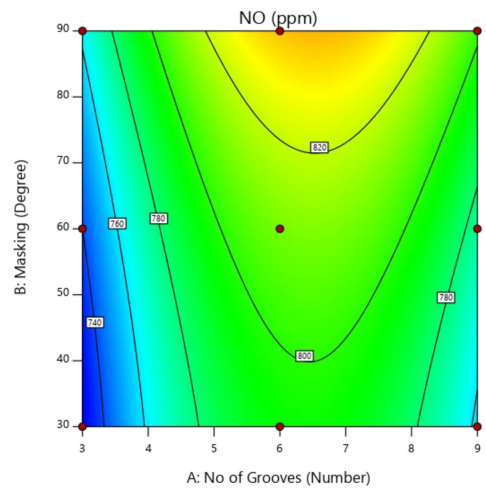

1B 2G

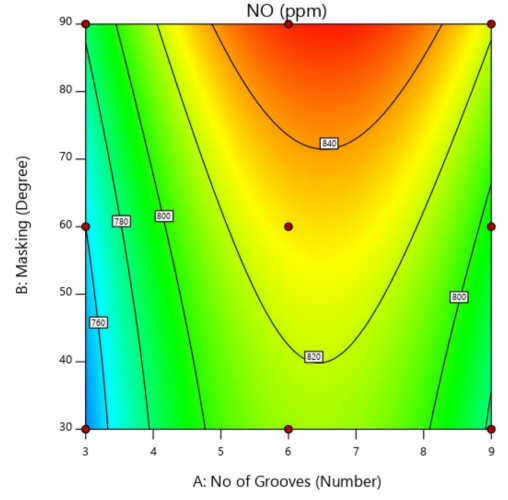

2B 3G

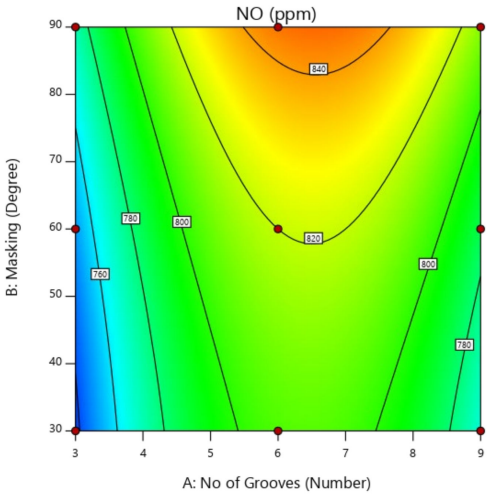

3B $4 \mathrm{G}$

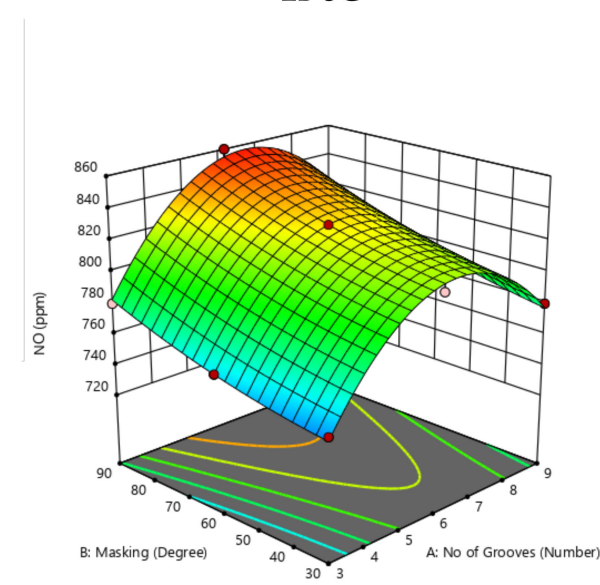

Figure 9. Effect of the 'IVM' and 'NG' on NOx emission.

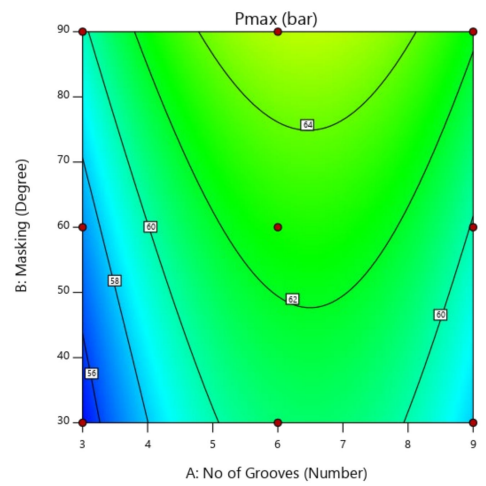

1B 2G

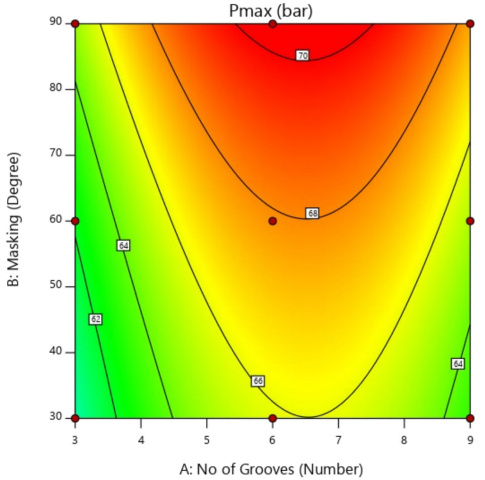

2B 3G

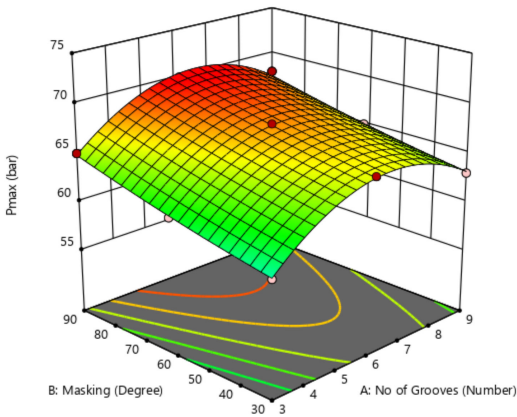

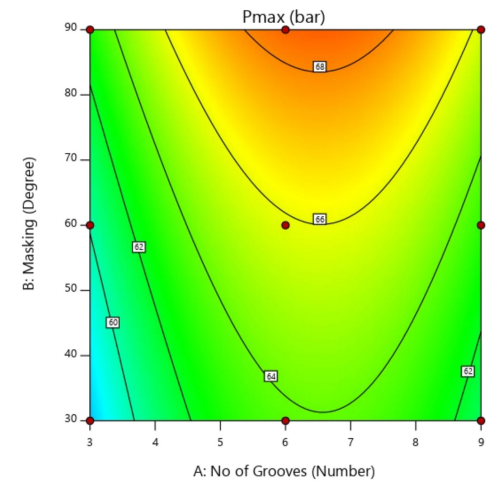

3B 4G

Figure 10. Effect of the 'IVM' and 'NG' on Pmax. 


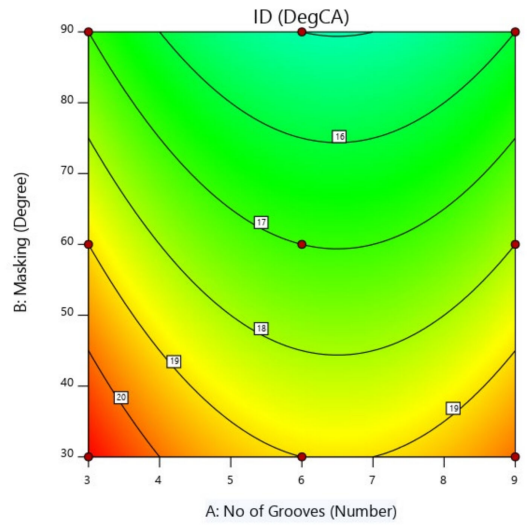

1B 2G

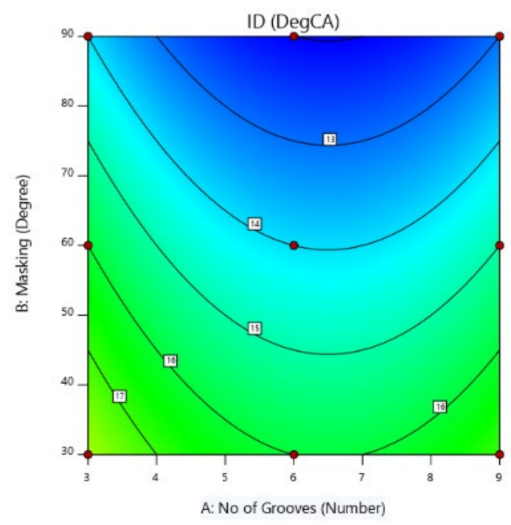

2B 3G

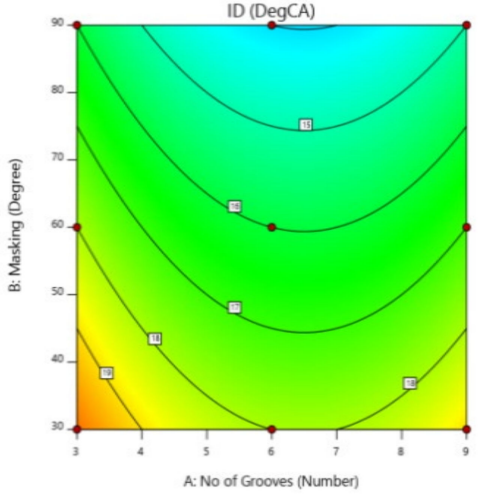

3B 4G

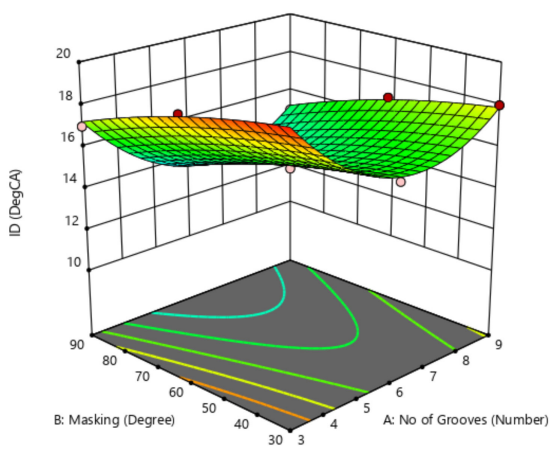

Figure 11. Effect of the 'IVM' and 'NG' on ignition delay.

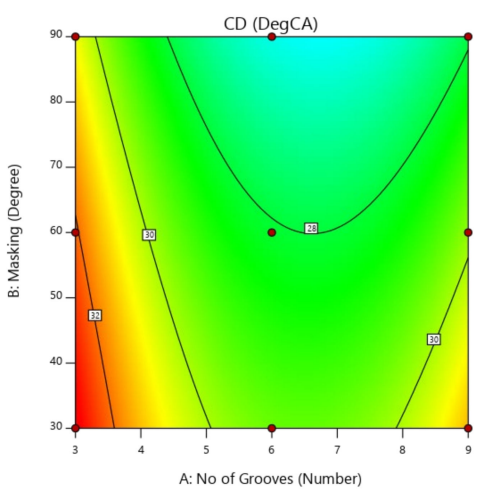

1B 2G

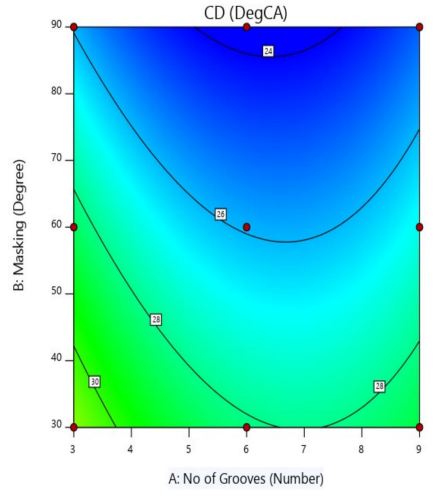

2B 3G

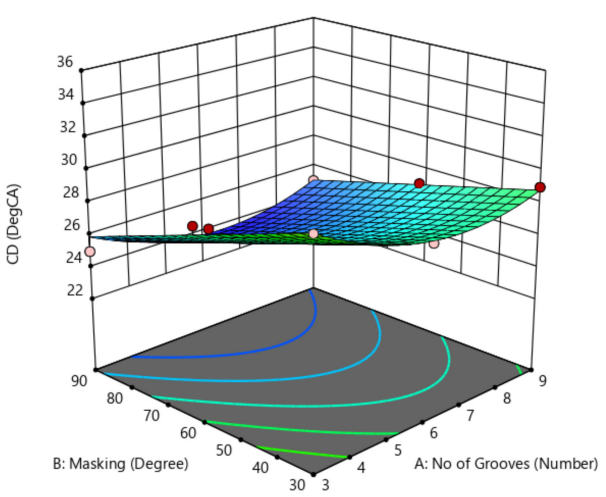

Figure 12. Effect of the 'IVM' and ' $N G$ ' on combustion duration. 


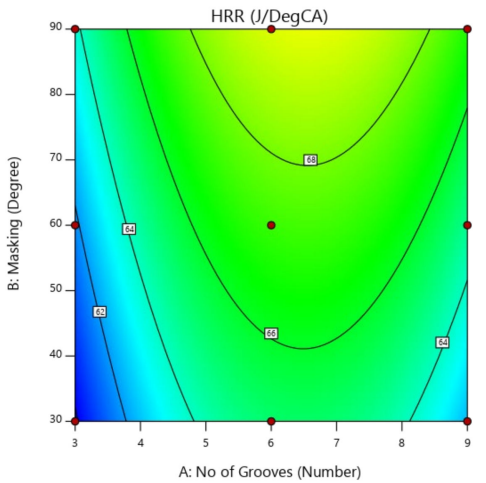

1B 2G

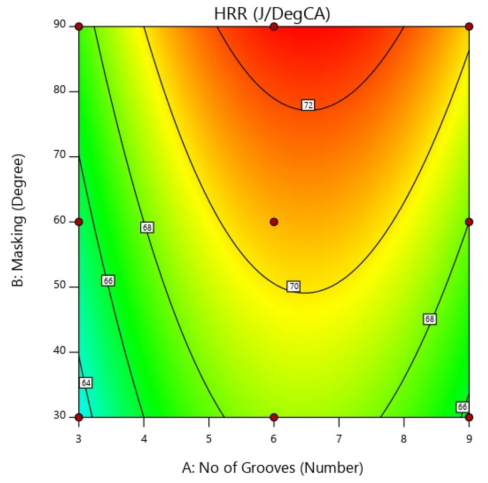

2B 3G

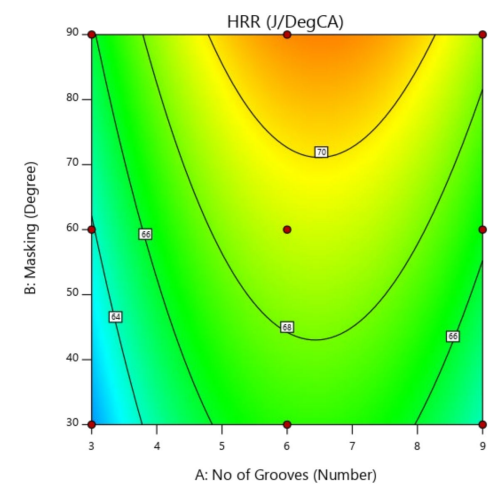

3B $4 \mathrm{G}$

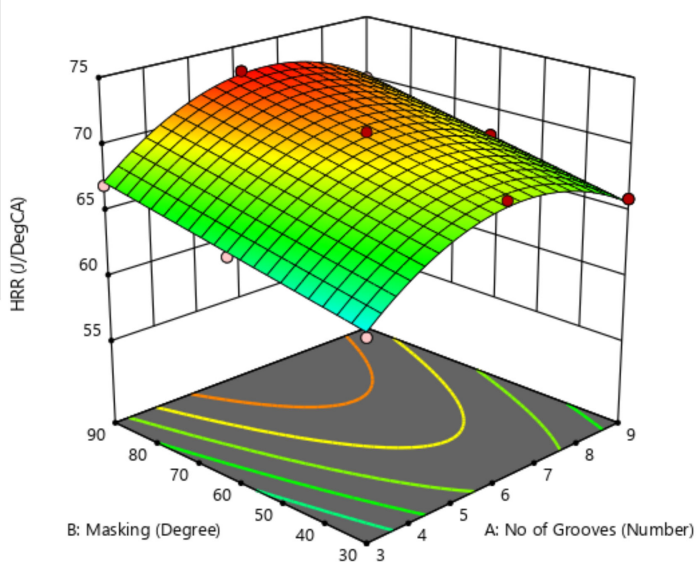

Figure 13. Effect of the 'IVM' and 'NG' on heat release rate.

The significance testing using ANOVA was carried out to validate the models after establishing the use of the RSM. If $p$-values were less than 0.05 , as given in Table 6 , the model terms were assumed to be significant and hence were able to describe $95 \%$ of the variability of the response, as reported in literature $[3,4,7,8]$. Table 7 shows the significant model terms for BTE, smoke, HC, CO, NOx, Pmax, ID, CD, and HRR predictor models. The $p$-values greater than 0.05 showed unimportant models, which are indicated by the terms in bold. Usually, the $p$ values for interactions are much more than 0.05 , which shows lack of fit, as also reported by $[25,26]$. This is because the interactions between predictor variables used in our works were arbitrarily taken, and it was quite possible that the particular combination may not be the best and hence usually ended up with $p$ values of more than 0.05 . Hence, there are endless design variabilities possible for interactions and we are supposed to use the best combination to maximize responses, which may have $p$ values less than 0.05 . It is usually very difficult to test different combinations in our works. Additionally, linear and quadratic models show lack of fit for input variable masking. The regressing statistics for rightness of fit $\left(\mathrm{R}^{2}\right)$ and the rightness of prognostication (Adjusting $R^{2}$ ) are provided in Table 7 for all the outcomes. The value of $R^{2}$ indicates the percentage variation of the outcome after the paramount factors were considered. The adjusting $R^{2}$ value gives an idea about the number of predictor inputs in the model. Both these values indicate that the models fit the experimental data sufficiently. The data fitting quality was expressed as a coefficient of multiple determination $\left(R^{2}\right)$ and rightness of prediction $\left(\right.$ Adj- $\left.R^{2}\right)$, but as the number of affecting variables increased, the $R^{2}$ value increased. Hence, adj- $\mathrm{R}^{2}$ was a better parameter, which is recommended to use as it decreases if unimportant terms are included, as reported by K. Ibrahim et al. [26]. Therefore, the regressing $R^{2}$ value 
can be preferably put forth as the percent of information utilized by the models from the data. For instance, $R^{2}$ equal to 0.94 informs us that the models account for over $94 \%$ of the changeability in the experimented data. The prima facie evidence from the $\mathrm{R}^{2}$ values in Table 8 shows that all outcomes in the assay had very good fittings. The HC emissions show lack of fit with the $R^{2}$ value of 0.9478 and predicted $R^{2}$ value of 0.8666 . HC is usually much less predictable as it is not smoothly related to other quantities, as reported by many researchers, H. Raheman et al., 2004 [6] and Z. Win et al., 2005 [23], with a R2 value of 0.669 . Along with ANOVA, the precise indexing values, such as $\mathrm{R}^{2}$, 'adjusting $\mathrm{R}^{{ }^{\prime}}$, and 'predicting $\mathrm{R}^{2^{\prime}}$, were also found to be adequate as they were nearer to the experimented values. The precise indexing values of the diverse predictor models are shown in Table 7. The press residuals, the predicting errors sum of squares (press) supposed by Allen (years 1971 and 1974), present a meaningful residual scale. Press can be utilized to evaluate a probable $R^{2}$ value for predictions, such as $R^{2}$ predictions $=1-($ Press $/ S S T)$.

Table 6. ANOVA evaluation for the responses indicating $p$-values.

\begin{tabular}{cccccccccc}
\hline Response & BTE & Smoke & HC & CO & NOx & Pmax & ID & CD & HRR \\
\hline Regression & 0.001 & 0.002 & 0.002 & 0.001 & 0.005 & 0.000 & 0.000 & 0.000 & 0.001 \\
Linear & 0.000 & 0.002 & 0.000 & 0.000 & 0.000 & 0.003 & 0.000 & 0.001 & 0.000 \\
Number of Grooves & 0.000 & 0.000 & 0.005 & 0.000 & 0.006 & 0.001 & 0.000 & 0.000 & 0.000 \\
Masking & 0.077 & 0.094 & 0.086 & 0.000 & 0.477 & 0.052 & 1.000 & 0.657 & 0.010 \\
Grooves & 0.002 & 0.002 & 0.003 & 0.000 & 0.003 & 0.001 & 0.000 & 0.002 & 0.000 \\
Square & 0.006 & 0.055 & 0.005 & 0.000 & 0.002 & 0.002 & 0.001 & 0.000 & 0.000 \\
Number of Grooves $*$ No of Grooves & 0.010 & 0.020 & 0.000 & 0.030 & 0.003 & 0.057 & 0.002 & 0.000 & 0.045 \\
Masking $*$ Masking & 0.714 & 0.492 & 0.429 & 0.248 & 0.004 & 0.029 & 0.010 & 0.310 & 1.000 \\
Grooves $*$ Grooves & 0.003 & 0.040 & 0.003 & 0.000 & 0.010 & 0.022 & 0.000 & 0.000 & 0.010 \\
Interaction & 0.063 & 0.083 & 0.413 & 0.013 & 0.170 & 0.406 & 1.000 & 0.216 & 0.304 \\
Number of Grooves $*$ Masking & 0.440 & 0.155 & 0.104 & 0.222 & 0.029 & 0.325 & 1.000 & 0.040 & 0.094 \\
Number of Grooves $*$ Grooves & 0.479 & 0.155 & 0.851 & 0.021 & 1.000 & 0.325 & 1.000 & 1.000 & 0.388 \\
Masking $*$ Grooves & 0.013 & 0.080 & 0.851 & 0.021 & 1.000 & 0.325 & 1.000 & 1.000 & 1.000 \\
\hline
\end{tabular}

Table 7. RSM model evaluation.

\begin{tabular}{|c|c|c|c|c|c|c|c|c|c|}
\hline Response & BTE & Smoke & HC & $\mathrm{CO}$ & NOx & Pmax & ID & $\mathrm{CD}$ & HRR \\
\hline Mean & 26.5139 & 59.7005 & 50.6666 & 0.27495 & 788.3333 & 62.8889 & 15.7777 & 29.1851 & 66.3333 \\
\hline Range & 7.8464 & 20.1944 & 20.0278 & 0.130833 & 137.5 & 16.25 & 8.3333 & 8.75 & 12.9167 \\
\hline Variance & 3.5902 & 33.026 & 26.3673 & 0.0009456 & 1158.333 & 13.8556 & 4.1234 & 5.6855 & 9.7109 \\
\hline $\begin{array}{l}\text { Standard } \\
\text { Deviation }\end{array}$ & 1.894 & 5.7468 & 5.1349 & 0.03075 & 34.0343 & 3.7223 & 2.0306 & 2.3844 & 3.1162 \\
\hline $\begin{array}{l}\text { Model } \\
\text { Degree }\end{array}$ & $\begin{array}{c}\text { Linear, } \\
\text { Quadratic } \\
\text { and } \\
\text { Interactive }\end{array}$ & $\begin{array}{l}\text { Linear and } \\
\text { Quadratic }\end{array}$ & $\begin{array}{l}\text { Linear and } \\
\text { Quadratic }\end{array}$ & $\begin{array}{l}\text { Linear and } \\
\text { Quadratic }\end{array}$ & $\begin{array}{l}\text { Linear and } \\
\text { Quadratic }\end{array}$ & $\begin{array}{l}\text { Linear and } \\
\text { Quadratic }\end{array}$ & $\begin{array}{l}\text { Linear and } \\
\text { Quadratic }\end{array}$ & $\begin{array}{c}\text { Linear } \\
\text { Quadratic } \\
\text { and } \\
\text { Interactive }\end{array}$ & $\begin{array}{l}\text { Linear and } \\
\text { Quadratic }\end{array}$ \\
\hline R2 & 99.58 & 98.50 & 94.78 & 99.67 & 99.29 & 99.62 & 98.82 & 98.08 & 99.32 \\
\hline PRESS & 0.598056 & 25.1137 & 99.2654 & 0.000236424 & 587.972 & 3.62095 & 3.33283 & 6.71292 & 4.65460 \\
\hline $\begin{array}{l}\text { Predicted } \\
\text { R2 }\end{array}$ & 98.76 & 96.30 & 86.66 & 99.10 & 98.13 & 98.99 & 97.04 & 95.02 & 98.24 \\
\hline $\begin{array}{l}\text { Adjusted } \\
\text { R2 }\end{array}$ & 99.35 & 97.70 & 92.01 & 99.49 & 98.91 & 99.41 & 98.19 & 97.07 & 98.95 \\
\hline
\end{tabular}


Table 8. ANOVA and R2 valuates for the fitted predictor models.

\begin{tabular}{ccccccccc}
\hline & \multicolumn{2}{c}{ Sum of Squares } & \multicolumn{2}{c}{ Degrees of Freedom } & \multicolumn{2}{c}{ Mean Square } & F-Ratio & \multirow{2}{*}{$\mathbf{R}^{2}$} \\
\cline { 2 - 6 } & Regression, SST & Residual & Regression & Residual & Regression & Residual & \\
\hline BTE & 48.0350 & 0.2042 & 9 & 17 & 5.3372 & 0.0120 & 444.37 & 0.9958 \\
Smoke & 669.417 & 10.213 & 9 & 17 & 74.38 & 0.601 & 123.81 & 0.9850 \\
HC & 705.139 & 38.861 & 9 & 17 & 78.349 & 2.286 & 34.27 & 0.9478 \\
CO & 0.026186 & 0.000088 & 9 & 17 & 0.002910 & 0.000005 & 562.31 & 0.9967 \\
NOx & 31275.0 & 225.0 & 9 & 17 & 3475.0 & 13.2 & 262.56 & 0.9929 \\
Pmax & 358.028 & 1.38 & 9 & 17 & 39.781 & 0.081 & 490.19 & 0.9962 \\
ID & 111.333 & 1.333 & 9 & 17 & 12.3704 & 0.0784 & 157.72 & 0.9882 \\
CD & 132.083 & 2.583 & 9 & 17 & 14.6759 & 0.1520 & 98.58 & 0.9808 \\
HRR & 262.194 & 1.806 & 9 & 17 & 29.1327 & 0.1062 & 274.3 & 0.9932 \\
\hline
\end{tabular}

The Fisher (F)-test was used to check the sufficiency of the RSM fittings-based modellings and was found to be adequately applicable at $95 \%$ assurance level. ANOVA summations are provided in Table 8, clearly notifying that the fitted model was satisfactory. The determination coefficient $\left(R^{2}\right)$ [24] was also evaluated (Table 8 ), showing good linkages among the experimented and prognosticated values for every outcome.

Looking at the values of range and standard deviation, it can be stated that there is considerable variation in values of responses and hence it justifies $3^{3}$ trials for DoE.

\section{Results and Discussions}

\subsection{RSM Analysis}

The response surface profiles and contours of the optimized characteristics are shown in Figures 5-13. For a combination of the 2B 3G cylinder head, IVM of $90^{\circ}$, and 'NG' of six grooves on piston RSM, analysis of the experimental results optimizes outcome responses as: BTE, 31.3679\%; smoke, $47.1852 \mathrm{HSU}$; HC emission, $40.2222 \mathrm{ppm}$; CO, $0.220741 \%$; NOx, 855.0 ppm; peak pressure, 70.4074 bar; ignition delay, $11.5556{ }^{\circ} \mathrm{CA}$; combustion duration, $24.4444^{\circ} \mathrm{CA}$, and heat release rate of $72.7778 \mathrm{~J} /{ }^{\circ} \mathrm{CA}$. This optimized condition was validated with an actual experiment. It is to be noted that, for the above combination, BTE was 31.3679\% for HOME in the CMFIS operation, which was equal to the BTE of diesel in the conventional engine. The above result had the highest NOx emissions of $855.0 \mathrm{ppm}$ due to the improved rate of combustion, which was much less than conventional diesel engine and, due to improved swirl and enhanced heat transfer to cylinder walls, was the main concept of this work. The highest NOx emissions may be due to an increased rate of swirling and proper fuel air mixture formation, resulting in maximum peak temperature attained in the cylinder, which enhanced formation of NOx. Hence, to reduce NOx emissions and its harmful effects on the formation of photochemical smog, we can look for other combinations. A combination of the 3B $4 \mathrm{G}$ cylinder head, IVM of $90^{\circ}$, and NG of three grooves on the piston optimized a low NOx of 772.5 ppm with BTE $26.0 \%$, a compromise of $5.3679 \%$ in BTE compared to the above combination.

\subsection{Performance Attributes \\ Brake Thermal Efficiency}

The outturns of Inlet Valve Masking (IVM) and Number of Grooves (NG) on BTE for a given bridge-groove configuration (BGC) at 80\% loading are presented in Figure 5. It is clear that the BTE enhances with increased IVM up to $90^{\circ}$, principally for enhanced swirl, resulting in improved air-fuel mixture formation, whereas, reduced IVM showed a decreasing trend of BTE. For a fixed bridge-groove configuration at $80 \%$ load, higher BTE was observed with and increased NG up to six, and beyond, this BTE decreased. Additionally, it is clear that the ID decreased to NG of six grooves, then exhibited increasing trends for the other value of 'BGC'. However, for given IVM and NG combinations, 'BGC' with the 2B 3G model showed the highest BTE. The reasons could be due to an increase in swirl, bridges, and grooves induced in a tumbling flow. Therefore, it can be inferred 
that lower ID at NG of six and IVM of $90^{\circ}$ facilitated higher combusting efficacy and lessoned heat escape in the cylinder due to escalated flaming temperatures and HRR. Similar inquests are written in literature by Ganapathy et al., [5] and Khoobbakht et al., [13]. The highest BTE achieved for NG of six and IVM of $90^{\circ}$ was $31.3679 \%$, which was 3.3679\% higher and 10.73\% more compared to the neat HOME operation in CI mode, which was $28 \%$. In their RSM studies, Hirkude et al., [7] reported an increase in BTE by $5.41 \%$ for B70 waste fried oil methyl ester (WFOME).

\subsection{Emission Attributes}

\subsubsection{Smoke Emissions}

Figure 6 depicts the variant smoke intensity with the 'IVM' for diverse 'NG' at $80 \%$ loading. For a given BGC at $80 \%$ loading, the smoke emitted decreased up to an 'IVM' of $90^{\circ}$ then showed an increasing tendency at other values of ' $\mathrm{NG}^{\prime}$. The rationale for this tendency may be due to better intermixing of fluids air and fuel and perfect combustion at 'IVM' of $90^{\circ}$ and 'NG' of six, resulting in high BTE. However, for a given IVM and NG, combinations of 'BGC' with the 2B 3G model showed the lowest smoke. The lower smoke emitted level attained was 47.1852 HSU in the CMFIS, working at an 'IVM' of $90^{\circ}$ and ' $N G$ ' of six, which was $44.11 \%$ lesser than the neat HOME utilized CI mode of engine working, which was 68 HSU. A similar reduction of smoke by $20 \%$ for B100 was reported by Raheman et al. [6] and Win et al. [20].

In addition, for only 2B 3G, operation of HSU reduced to $54 \mathrm{HSU}$, which was around 66 HSU for an 'IVM' of only $90^{\circ}$ or ' $\mathrm{NG}^{\prime}$ of only six in CMFIS operation taken from our previous work. Now, their combination reduced smoke emissions to $47.1852 \mathrm{HSU}$.

\subsubsection{HC Emissions}

$\mathrm{HC}$ emittance tendency with the 'IVM' and 'NG' is presented in Figure 7 for the BDF injected, i.e., HOME in the CMFIS mode. For a given BGC at $80 \%$ loading, the HC emission decreased up to an 'IVM' of $90^{\circ}$ then tended to increase at any other value of 'NG'. The rationale for this trend may be due to an idealized combustion of fuel injecting, resulting in high BTE at an 'IVM' of $90^{\circ}$ and ' $\mathrm{NG}^{\prime}$ ' of six. However, a given IVM and NG combinations 'BGC' with the 2B 3G model showed the lowest HC emissions. The lesser $\mathrm{HC}$ emissions level attained was $40.2222 \mathrm{ppm}$ in the CMFIS, working at an 'IVM' of $90^{\circ}$ and an 'NG' of six, which was $38.12 \%$ lower when contrasted to the neat HOME fueled CI mode of working, which was 65 ppm. Additionally, for the opposite trend of increased HC emissions with other bridge-groove combinations, the possible reason might be due to an insufficient swirl developed for a 1B2G cylinder head and too much turbulence induced for the 2B3G cylinder head, not allowing proper air-fuel mixture formation. A similar work is reported by Najafi [10], using biodiesel in a diesel prime mover, resulting in lessoned competence, increased fuel intake, and UBHC and carbon CO, emitted with curtailed NOx gas formation.

\subsubsection{CO Emissions}

Figure 8 portrays the nature of CO emitted for HOME fueled CMFIS, working at $80 \%$ loading. Large heat unleashing in the pre-mixed uncontrolled burning phases rather than the diffusing or controlled burning phases is always amenable for lowered $\mathrm{CO}$ emission. $\mathrm{CO}$ emitted strongly depends on the air fuel $(\mathrm{A} / \mathrm{F})$ ratios linked to stoichiometric proportions. Richer combustion inevitably ends in more $\mathrm{CO}$ emissions and increases linearly with the air fuel $(\mathrm{A} / \mathrm{F})$ ratios other than the stoichiometric A/F ratio. For a given BGC, at $80 \%$ load-increased 'IVM' up to $90^{\circ}$ showed lowered CO emissions similar to $\mathrm{HC}$ emissions at any given value of ' $\mathrm{NG}^{\prime}$. At ' $\mathrm{IVM}$ ' of $90^{\circ}$ and ' $\mathrm{NG}^{\prime}$ of six, the lowest $\mathrm{CO}$ emanations were seen. The rationale may increase in local temperatures and improve $\mathrm{CO}$ oxidation to $\mathrm{CO}_{2}$, as reported in the literature $[3,7,16]$, which is similar with our findings. However, for a given IVM and NG, combinations 'BGC' with the 2B 3G model showed the lowest $\mathrm{CO}$ emissions. The least CO emanations level attained was $0.220741 \%$ in the CMFIS, work- 
ing at 'IVM' of $90^{\circ}$ and 'NG' of 6, which was considerably less compared with the neat HOME utilized CI mode of engine working, which was $0.35 \%$, thus reduced by $58.55 \%$. This satisfies emission standards BS 6 and Euro 6. Additionally, for the opposite trend of increased $\mathrm{CO}$ emissions with other bridge-groove combinations, the possible rationale might be an unsuitable swirl and lesser time available for the perfect combustion, similar to the work of Najafi [10], which used biodiesel in a diesel prime mover and resulted in inferior competence, increased fuel intake, and UBHC and CO emitted with lessoned NOx formation.

\subsubsection{NOx Emissions}

The NOx emissions measured for CMFIS mode at $80 \%$ loading are indicated in Figure 9. The NOx gas emitted is meliorated by enhanced cylinder pressures and charge temperatures. Elated NOx emitted for BDF HOME might be due to the presence of a large oxygen content of the oil chemical structure itself. A notified BGC at $80 \%$ load that increased IVM up to $90^{\circ}$ showed increased NOx concentration at first and then a decreasing tendency for any given value of 'NG' under CMFIS operation. A suitable description for this could be due to the enhanced temperatures registered inside the cylinder for the uncontrolled combustion stage at IVM of $90^{\circ}$ and NG of 6 , which ended in larger NOx. Similarly, Pandal et al. [16] reported elated BTE and NOx with lesser BSFC, HC, and CO at optimal IT of $21^{\circ} \mathrm{bTDC}$, IOP of $225 \mathrm{bar}$, and nozzle tip protuberance of $2.5 \mathrm{~mm}$.

However, a given IVM and NG combinations of BGC with the 2B 3G model showed the highest NOx emissions of 855 ppm, which were $18.01 \%$ less contrasted with the neat HOME utilized CI mode of working, which was 1009 and 900 ppm, respectively, with and without bridge-groove configuration. Lowered NOx emitted with other combinations may be linked to low combusting temperatures. Similar inquests are written in literature $[14,22,27]$. Use of biodiesel resulted in lessoned BTE and enhanced BSFC, CO, and HC emittance with lowered NOx formed, as reported by Najafi [10]. It is to be noted that, for diesel engine simulation, fueled with HOME, when implementing a combination of 1B 2G cylinder heads, an IVM of $30^{\circ}$, and NG of 3 grooves on the piston optimizes a low NOx of $717.5 \mathrm{ppm}$, BTE decreased slightly from $31.3679 \%$ to $23.5215 \%$. This was much less than that for neat HOME in a conventional engine, i.e., $1009 \mathrm{ppm}$. Hence, the percentage reduction of NOx was about $40.62 \%$. This suffices, to some extent, emission standards BS 6 and Euro 6, which are planning to reduce NOx by a staggering 70\% compared to BS 4 and Euro 5 . Thus, by making further design changes in the above combination, NOx may be decreased towards $70 \%$.

\subsection{Combustion Attributes}

\subsubsection{Peak Pressure (Pmax, PP)}

The variant PP for HOME fueled CMFIS working at diverse IVM and NG is put forth in Figure 10. The PP is influenced by contained energy and the dynamic viscous nature of the injecting fuel. At an IVM of $90^{\circ}$ and NG of 6, cylinder gas pressure was the highest. The lessoned ID and $\mathrm{CD}$ could be the reason for these set conditions making combusting reactions, faster ending at enhanced PP. However, a given a IVM and NG combinations of BGC with the 2B 3G model showed the highest peak pressure of 71.4074 bar. However, the PP in a neat HOME utilized $\mathrm{CI}$ engine working with and without bride-groove configuration was 70 and 50 bar, respectively. Therefore, comparing PP in neat HOME injected CI engine operation without bride-groove configuration, it was 30\% lower than the optimized value.

\subsubsection{Ignition Delay (ID)}

The behavior of ID with IVM and NG for different BGC is shown in Figure 11. The charge in temperatures during compression, heat energy unleashed in premixed combustion, heat conveyed to the surrounding materials, and the residue gas quantity appears to be the prime factors amenable for changes in ID crank angles. The ID value was evaluated based on the static injection timing, considering pressure crank angles data for 100 power 
cycles. For the IVM of $90^{\circ}$ and NG of 6 , shorter ID was noted because of the highest charge temperatures. However, the ignition delay duration increased for either increasing or decreasing IVM and NG from the optimized values due to lessoned temperatures prevailing. However, a given IVM and NG combinations of BGC with the 2B 3G model showed lower ID of $11.5556{ }^{\circ} \mathrm{CA}$, which was $55.76 \%$ (without BGC) lower than the ID in neat HOME fueled $\mathrm{CI}$ engine operation with and without bridge-groove configuration, i.e., 13 and 18 degrees, respectively. Though ID decrease, it marginally results in PP nearer to TDC position, which acts through larger lengths of strokes, leading to more displacement work done and higher BTE.

\subsubsection{Combustion Duration (CD)}

The variant $C D$, as in Figure 12, has been calculated as the duration between the SOC and $90 \%$ net heat unleashed. In addition, total CD is the time length of the net fuel oxidation processes and is the summation of the flames establishment period. For a given BGC at $80 \%$ load, an IVM of $90^{\circ}$ and NG of 6 lower CD was noticed due to higher cylinder temperatures prevailing inside the engine cylinder. Similar inquests are written in literature [16]. The high BTE due to rapid-fire and more combusting intensity with the shortest ID in both stages of the HRR demonstrates the noticed results.

However, a given IVM and NG combinations of BGC with the 2B 3G model showed higher $\mathrm{CD}$ of $24.4444^{\circ} \mathrm{Ca}$, which was $43.18 \%$ lower than the $\mathrm{CD}$ in neat HOME fueled CI engine operation with and without bridge-groove configuration, which was 32 and $35^{\circ} \mathrm{CA}$, respectively. Reduced CD resulted in decreased burning time loss, enhancing competence. Additionally, though CD decreased marginally, it resulted in a shifting of PP towards the TDC position, which acted through larger stroke lengths, resulting in more work done and higher BTE.

\subsubsection{Heat Release Rate (HRR)}

Figure 13 portrays the variant HRR for CMFIS mode of prime mover, running at diverse IVM and NG for a given BGC. For the given NG, the HRR varies first with increasing tendency up to $90^{\circ}$, as presented in Figure 11. At IVM of $90^{\circ}$ and NG of 6 , maximized HRR was realized, which might be because of more heat unleashed in the uncontrolled combusting phase. Meliorated air fuel mixture forming, and consequently swift combusting, could have rendered for higher HRR. However, a given IVM and NG combinations of BGC with the $2 \mathrm{~B} 3 \mathrm{G}$ model showed higher $\mathrm{HRR}$ of $72.7778 \mathrm{~J} /{ }^{\circ} \mathrm{CA}$, which was $17.55 \%$ higher than the HRR in neat HOME fueled $\mathrm{CI}$ engine operation with and without bridge-groove configuration, i.e., $70,60 \mathrm{~J} /{ }^{\circ} \mathrm{CA}$, respectively. Faster HRR meliorates competence, and thus we can design high speed engines.

\section{Validation of Test Results}

\subsection{Validation of Test Results for Optimized Conditions}

The experimental work conducted thrice at the predictor variables of the piston with six numbers of grooves (NG), $90^{\circ}$ inlet valve masking (IVM), and five numbers combinations of bridges-n-grooves on cylinder heads ( $\mathrm{Br}-\mathrm{Gr}$ ) for validating the predicted results. An optimum IOP of 240 bar and injecting time of $27^{\circ} \mathrm{bTDC}$ resulted in overall better performance at $80 \%$ load and for a five-hole injector with a $0.3 \mathrm{~mm}$ hole size. For the actual value of outputs, the mean of three experimental results was considered. The summary of the theoretical RSM values, the mean of the measured values, and the percent error between them is given in Table 9. This validates that the models generated were accurate as the percent error in predictions agreed well with actual values. 
Table 9. Validation of test results.

\begin{tabular}{cccccccccc}
\hline Response & $\begin{array}{c}\text { BTE } \\
\mathbf{\%}\end{array}$ & $\begin{array}{c}\text { Smoke } \\
\text { HSU }\end{array}$ & $\begin{array}{c}\text { HC } \\
\mathbf{p p m}\end{array}$ & $\begin{array}{c}\text { CO } \\
\mathbf{\%}\end{array}$ & $\begin{array}{c}\text { NOx } \\
\mathbf{p p m}\end{array}$ & $\begin{array}{c}\text { Pmax } \\
\text { Bar }\end{array}$ & ID $\left({ }^{\circ} \mathbf{C A}\right)$ & CD $\left({ }^{\circ} \mathbf{C A}\right)$ & $\begin{array}{c}\text { HRR } \\
\left(\mathrm{J} /{ }^{\circ} \mathbf{C A}\right)\end{array}$ \\
\hline Predicted & 31.3679 & 47.1852 & 40.2222 & 0.220741 & 855.0 & 71.4074 & 11.5556 & 24.4444 & 72.7778 \\
\hline Actual & 29.94 & 55 & 46 & 0.24 & 820 & 66 & 14 & 32 & 67 \\
\hline Error $\%$ & -4.5521 & 16.56 & 14.36 & 8.72 & -4.09 & -7.572 & 21.15 & 30.91 & -7.938 \\
\hline
\end{tabular}

\subsection{Emission Norms Set by Worldwide Councils and Validation of Engine Test} $\mathrm{g} / \mathrm{kwh}$.

In BS 6 and Euro 6, the mass of pollutants emitted are computed by the equation in

$$
\begin{gathered}
M=\frac{\left.\left(m_{f}+m_{a}\right) \times 1000 \times 3600\right)}{28} \times \frac{(\mathrm{NOx} \text { in } p p m)}{1,000,000} \times \frac{30}{B P} \\
M=\frac{(0.00019531+0.007982) \times 1000 \times 3600)}{28} \times \frac{(220)}{1,000,000} \times \frac{30}{1.04} \\
M=6.641 \mathrm{~g} / \mathrm{kWh}
\end{gathered}
$$

In which $m_{f}+m_{a}=$ mass of fuel and air in $\mathrm{kg} / \mathrm{s}$. and $B P=$ brake power output of the engine.

Additionally, in BS 6 and Euro 6, the mass of pollutants emitted are computed by the equation in $\mathrm{g} / \mathrm{km}$ :

$$
M i=\left[\frac{Q i \times C i \times K H \times V_{\text {mix }} \times 10^{-6}}{d}\right]
$$

In which $M i=$ Emission of the pollutant in $\mathrm{g} / \mathrm{km}$

$V m i x=$ Exhaust gases volume diluted expressed in $\mathrm{m}^{3}$ for the test and then corrected to normal pressure and temperatures $101.33 \mathrm{kPa}$. and $293 \mathrm{~K}$.

$Q i=$ Pollutant i density in $\mathrm{kg} / \mathrm{m}^{3}$ at $101.33 \mathrm{kPa}$ and $293 \mathrm{~K}$, standard conditions.

$k H=$ Correction factor for humidity used for calculating the mass emission of nitrogen oxides. Such correction is not needed for $\mathrm{CO}$ and HC.

$\mathrm{C} i=$ Pollutant $\mathrm{i}$ concentration in ppm of the dilute exhaust gases and correction made by the quantity of the pollutant i present in the diluting air.

$d=$ Distance travelled in $\mathrm{km}$.

The Central Pollution Control Board (CPCB), along with the Ministry of Forests and Environment in India, laid down emission regulations for diesel gensets (Figure 14), its logo. Permissible limits of emissions and other CPCB regulations that diesel genset manufacturers and users should be aware of are set. According to $\mathrm{CPCB}$, the emission of NOx and $\mathrm{HC}$ in a diesel generator up to $19 \mathrm{~kW}$ output power should not exceed $7.5 \mathrm{~g} / \mathrm{kW}-\mathrm{h}$. The emissions of CO should not be more than $3.5 \mathrm{~g} / \mathrm{kW}-\mathrm{h}$, while that of particulate matter not exceed $0.3 \mathrm{~g} / \mathrm{kW}$-h. An expert committee estimated that only cars released approximately 48.678 tons of NOx in the year 2016 in the national capital of New Delhi, causing serious health problems. This November 2019, the Air Quality Index (AQI) of Delhi is 613 and extremely hazardous to health, and we can contrast it with the safe and good AQI range of 0-50. 


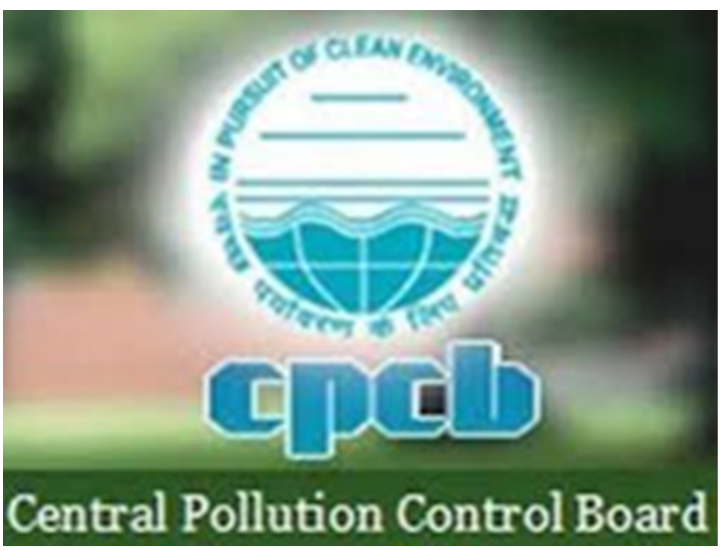

Figure 14. Logo of Central Pollution Control Board.

The Conseil International Des Machines A Combustion (CIMAC), Frankfurt/Main (Website www.cimac.com) Germany (Figure 15), guide to diesel exhaust emissions control of $\mathrm{NO}_{\mathrm{x}}, \mathrm{SO}_{\mathrm{x}}$, particulates, smoke, and $\mathrm{CO}_{2}$ - seagoing ships, big and small stationary diesel power plants, and units gives some background information on diesel exhaust gas components and their environmental impact, along with a short overview of the most important existing and upcoming regulations and various existing and future potential emission abatement technologies. CIMAC was founded in Paris in 1951, which is The International Council on Combustion Engines.

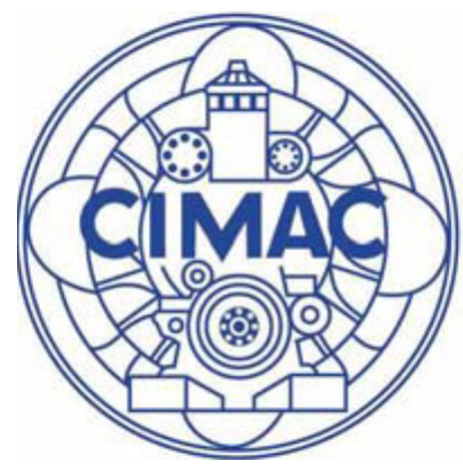

Figure 15. Logo of Conseil International Des Machines a Combustion.

The European Union and USA both set up the International Maritime Organization (IMO) for NOx regulations. Accordingly, inland waterways and engines with a per cylinder displacement of less than $30 \mathrm{~L} /$ cylinder have a maximum permitted value for NOx emissions at 7.2 to $11 \mathrm{~g} / \mathrm{kWh}$, depending on engine size.

The following Tables 10 and 11 show load tests carried out on the engine, with optimized conditions and emissions calculated in $\mathrm{g} / \mathrm{kWh}$. It can be seen that all values of $\mathrm{HC}$ emissions are less than $7.5 \mathrm{~g} / \mathrm{kW}$-h, which is the maximum permitted value as per СРCB India and is also less than $11 \mathrm{~g} / \mathrm{kW}-\mathrm{h}$, which is the maximum permitted value as per CIMAC and USA. Additionally, only the first value of NOx emissions is less than $7.5 \mathrm{~g} / \mathrm{kW}$-h, but others are more as per СРCВ. However, two values of NOx emissions are less than $11 \mathrm{~g} / \mathrm{kW}-\mathrm{h}$, but others are more as per CIMAC and USA. Furthermore, all the values of $\mathrm{CO}$ emissions are more than $3.5 \mathrm{~g} / \mathrm{kW}-\mathrm{h}$, which is the maximum permitted value as per CPCB India. Therefore, as the emissions are less than or very close to the norms, it can be stated that inlet valve masking (IVM), number of piston grooves (NG), and cylinder head bridge-groove configuration (BGC) can be implemented for any diesel engines. 
Table 10. Observations of load test on diesel engine at optimised conditions.

\begin{tabular}{cccccccc}
\hline S.No & $\mathbf{N}(\mathbf{r p m})$ & $\begin{array}{c}\text { Time for 20 cc Fuel } \\
\text { Consumption } \mathbf{( s )}\end{array}$ & $\begin{array}{c}\text { Air Consumption } \\
\left(\mathbf{m}^{\mathbf{3}} \mathbf{/ h}\right)\end{array}$ & $\begin{array}{c}\text { EGT } \\
\left({ }^{\circ} \mathbf{C}\right)\end{array}$ & $\begin{array}{c}\mathbf{N O}_{\mathbf{x}} \\
(\mathbf{p p m})\end{array}$ & $\begin{array}{c}\text { HC } \\
(\mathbf{p p m})\end{array}$ & $\begin{array}{c}\text { CO } \\
(\mathbf{\%}) \mathbf{p o l}) / \mathbf{p p m}\end{array}$ \\
\hline 1 & 1500 & 84.99 & 28.1 & 170 & 220 & 20 & $0.05 / 500$ \\
2 & 1500 & 69.78 & 30.46 & 216 & 380 & 25 & $0.08 / 800$ \\
3 & 1500 & 53.53 & 30.89 & 250 & 520 & 30 & $0.10 / 1000$ \\
4 & 1500 & 34.50 & 28.57 & 325 & 710 & 45 & $0.15 / 1500$ \\
5 & 1500 & 31.63 & 29.29 & 340 & 850 & 70 & $0.28 / 2800$ \\
\hline
\end{tabular}

Table 11. Validation of test emission results as per CPCB India, the European Union, and USA.

\begin{tabular}{|c|c|c|c|c|c|c|c|c|c|c|}
\hline $\begin{array}{l}\text { Brake Power } \\
(\mathbf{k W})\end{array}$ & $\begin{array}{c}\text { Mass of Fuel } \\
(\mathrm{kg} / \mathrm{s})\end{array}$ & $\begin{array}{c}\text { BSFC } \\
(\mathrm{g} / \mathrm{kWh})\end{array}$ & $\begin{array}{c}\text { Mass of } \\
\text { Air (kg/s) }\end{array}$ & $\begin{array}{c}\mathrm{A} / \mathrm{F} \\
\text { Ratio }\end{array}$ & $\begin{array}{l}\text { BMEP } \\
\text { (Bar) }\end{array}$ & $\begin{array}{l}\text { BTE } \\
(\%)\end{array}$ & $\begin{array}{c}\text { Volumetric } \\
\text { Efficiency (\%) }\end{array}$ & $\begin{array}{c}\mathrm{NO}_{x} \\
(\mathrm{~g} / \mathrm{kWh})\end{array}$ & $\begin{array}{c}\mathrm{CO} \\
(\mathrm{g} / \mathrm{kWh})\end{array}$ & $\begin{array}{c}\mathrm{HC} \\
(\mathrm{g} / \mathrm{kWh})\end{array}$ \\
\hline 1.04 & 0.00019531 & 417.63 & 0.007982 & 40.86 & 1.27 & 16.98 & 88.61 & 6.641 & 15.16 & 1.78 \\
\hline 2.08 & 0.00023789 & 287.93 & 0.008293 & 34.86 & 2.54 & 24.22 & 86.89 & 10.81 & 12.65 & 2.22 \\
\hline 3.12 & 0.00031010 & 236.33 & 0.008411 & 27.12 & 3.81 & 27.87 & 86.67 & 16.17 & 10.78 & 2.67 \\
\hline 4.16 & 0.00048110 & 226.48 & 0.007778 & 16.17 & 5.08 & 29.94 & 84.52 & 22.08 & 11.48 & 4.00 \\
\hline 5.20 & 0.00052475 & 211.53 & 0.007974 & 15.19 & 6.35 & 27.45 & 80.65 & 26.43 & 17.65 & 6.23 \\
\hline
\end{tabular}

The emissions of $\mathrm{CO}$ for non-road diesel engines should not be more than $3.5 \mathrm{~g} / \mathrm{kW}-\mathrm{h}$ as per CPCB, BS VI norms. Diesel is proven to be a good fuel for diesel engines but, for diesel, these norms are not satisfied as all the values of $\mathrm{CO}$ emissions are more than $3.5 \mathrm{~g} / \mathrm{kW}$-h. Thus, for any blends of diesel with biodiesels, $\mathrm{CO}$ emissions are more than that of diesel due to incomplete combustion. For 100\% HOME biodiesel, in conventional engines, these norms were not satisfied as all the values of $\mathrm{CO}$ emissions were more than $3.5 \mathrm{~g} / \mathrm{kW}-\mathrm{h}$ and considerably more than diesel due to poor combustion. However, for $100 \%$ HOME biodiesel with optimized combination of inlet valve masking (IVM) of $90^{\circ}$ and number of piston grooves (NG) of 6 grooves on piston crown and cylinder head bridge-groove configuration (BGC) of 2B 3G, CO emissions are considerably reduced from $46.0 \mathrm{~g} / \mathrm{kW}-\mathrm{h}$ to $17.65 \mathrm{~g} / \mathrm{kW}-\mathrm{h}$, if we take the last readings for a full load of $5.2 \mathrm{~kW}$, as given in Table 12. Thus, we can conclude that, for CO, BS VI norms cannot be satisfied only from engine research, as reported by Resitoglu et al. [18], and may be satisfied by on board equipment, such as a (diesel oxidation catalyst (DOC). According to RSM studies, at $80 \%$ load, the lowest percentage of CO emissions is $0.220741 \%$ or $2207.41 \mathrm{ppm}$. at the same above optimum combinations, for which CO emissions are $16.90 \mathrm{~g} / \mathrm{kW}-\mathrm{h}$, which is more than the corresponding value of the validation experiment, i.e., $11.48 \mathrm{~g} / \mathrm{kW}$-h, as given in Table 11.

Table 12. Comparison of CO emissions for diesel and HOME in conventional diesel engine and for validation test.

\begin{tabular}{|c|c|c|c|c|c|c|c|}
\hline \multirow[t]{2}{*}{ S.No } & \multirow[t]{2}{*}{ Brake Power (kW) } & \multicolumn{2}{|c|}{ For Diesel } & \multicolumn{2}{|c|}{ For HOME } & \multicolumn{2}{|c|}{ For Validation Test } \\
\hline & & $\begin{array}{c}\text { CO } \\
(\% \text { vol }) / p p m\end{array}$ & $\begin{array}{c}\mathrm{CO} \\
(\mathrm{g} / \mathrm{kWh})\end{array}$ & $\begin{array}{c}\text { CO } \\
(\% \text { vol }) / p p m\end{array}$ & $\begin{array}{c}\mathrm{CO} \\
(\mathrm{g} / \mathrm{kWh})\end{array}$ & $\begin{array}{c}\mathrm{CO} \\
(\% \mathrm{vol}) / \mathrm{ppm}\end{array}$ & $\mathrm{CO}(\mathrm{g} / \mathrm{kWh})$ \\
\hline 1 & 1.04 & $0.03 / 300$ & 9.906 & $0.08 / 800$ & 24.25 & $0.05 / 500$ & 15.16 \\
\hline 2 & 2.08 & $0.04 / 400$ & 6.320 & $0.09 / 900$ & 14.23 & $0.08 / 800$ & 12.65 \\
\hline 3 & 3.12 & $0.06 / 600$ & 6.46 & $0.12 / 1200$ & 12.93 & $0.10 / 1000$ & 10.78 \\
\hline 4 & 4.16 & $0.1 / 1000$ & 10.78 & $0.25 / 2500$ & 19.13 & $0.15 / 1500$ & 11.48 \\
\hline 5 & 5.20 & $0.35 / 3500$ & 22.06 & $0.73 / 7300$ & 46.01 & $0.28 / 2800$ & 17.65 \\
\hline
\end{tabular}

4.3. Theoretical Calculations of Approximate Emission of Greenhouse Gases $\mathrm{CO}_{2}$ and $\mathrm{NO}_{2}$ Based on Diesel Consumption by Vehicles in $\mathrm{g} / \mathrm{km}$

In total, $1 \mathrm{~L}$ of diesel weighs $835 \mathrm{~g}$ if specific gravity is 0.835 . Diesel consists of about $86.2 \%$ of carbon or $720 \mathrm{~g}$ of carbon per liter. We know that $12 \mathrm{~g}$ of carbon needs $32 \mathrm{~g}$ of oxygen and burns to form $44 \mathrm{~g}$ of $\mathrm{CO}_{2}$. Hence, for the complete combustion of $720 \mathrm{~g}$ of this carbon to $\mathrm{CO}_{2}$, carbon needs $(720 \times 32) / 12=1920 \mathrm{~g}$ of oxygen. The sum is then 
$720+1920=2640 \mathrm{~g}$ of $\mathrm{CO}_{2} /$ liter diesel. An average diesel consumption of $5 \mathrm{~L} / 100 \mathrm{~km}$ by a vehicle then corresponds to $5 \times 2640 \mathrm{~g} /$ liter $/ 100 \mathrm{~km}=132 \mathrm{~g} \mathrm{CO}_{2} / \mathrm{km}$. If $1920 \mathrm{~g}$ of oxygen is used, then $2.33 \times 1920=4480 \mathrm{~g}$ of nitrogen is used, then, $(4480 \times 32) / 14=10,240 \mathrm{~g}$ of oxygen is needed for the formation of $\mathrm{NO}_{2}$ if it is completely oxidized. This oxygen is taken from large amount of air available in the engine cylinder. The sum is then $4480+10,240=14,720 \mathrm{~g}$ of $\mathrm{NO}_{2}$. Therefore, an average diesel consumption of $5 \mathrm{~L} / 100 \mathrm{~km}$ by a vehicle then corresponds to $5 \times 14,720 \mathrm{~g} / \mathrm{liter} / 100 \mathrm{~km}=736 \mathrm{~g} \mathrm{NO}_{2} / \mathrm{km}$. However, if about $75 \%$ of the nitrogen exhaust is $\mathrm{N}_{2}$, then the remaining $25 \%$ burns to form $\mathrm{NO}_{2}$. Hence, the quantity of $\mathrm{NO}_{2}$ formed is $0.25 \times 736=184 \mathrm{~g} \mathrm{NO}_{2} / \mathrm{km}$. The carbon content of biodiesel is $76.5 \%$ or less, hence the above values shall reduce proportionately.

\section{Conclusions}

1. RSM is a powerful optimization tool for diesel engines fueled with HOME. Significant outcomes on the competence and emission attributes were assayed. A second-degree model was prosperously established to narrate the linkages among input parameter grooves on piston, inlet valve masking, and bridges and grooves on cylinder heads on output responses.

2. Optimal input variables for maximizing performance and minimizing emissions, except NOx, are 2B 3G cylinder head, 'IVM' of $90^{\circ}$, and 'NG' of 6 grooves on the piston. RSM analysis of the experimental results optimizes outcome responses, as given below in Table 13 .

Table 13. RSM analysis with optimized outcome responses.

\begin{tabular}{|c|c|c|c|c|c|c|c|c|c|c|c|c|}
\hline \multirow{3}{*}{ Trial No. } & \multicolumn{3}{|c|}{ Parameter Settings } & \multicolumn{9}{|c|}{ Fitted Responses (80\% Load) } \\
\hline & No. of & Masking & BR-GR & BTE & Smoke & $\mathrm{HC}$ & $\mathrm{CO}$ & NOx & Pmax & $\begin{array}{c}\text { ID } \\
{ }^{\circ} \mathrm{CA}\end{array}$ & $\begin{array}{l}\text { CD } \\
{ }^{\circ} \mathrm{CA}\end{array}$ & $\begin{array}{c}\text { HR } \\
\mathbf{R}\end{array}$ \\
\hline & & (Degree) & & $(\%)$ & (HSU) & (ppm) & $(\%)$ & (ppm) & (Bar) & & & $\mathrm{J} /{ }^{\circ} \mathrm{CA}$ \\
\hline 1 & 3 & 30 & $1 B-2 G$ & 23.5215 & 67.3796 & 60.2500 & 0.351574 & 717.5 & 55.1574 & 19.8889 & 33.1944 & 59.8611 \\
\hline 17 & 6 & 90 & $2 B-3 G$ & 31.3679 & 47.1852 & 40.2222 & 0.220741 & 855.0 & 71.4074 & 11.5556 & 24.4444 & 72.7778 \\
\hline
\end{tabular}

Although trial no 17 maximizes BTE, NOx is also maximum. However, for trial no 1, NOx is the minimum, but BTE decreases considerably as shown in Table 13.

3. Provision of bridges and grooves on the cylinder head proves to be very effective as they reduce emissions considerably. Additionally, a slight change in configuration of bridges and grooves can change flow directions and patterns and vary the way gases react, thus may reduce emissions further.

4. In RSM assay, BTE achieved for 'NG' of 6 and 'IVM' of $90^{\circ}$ and 2B 3G cylinder head for HOME is $31.3679 \%$, which is equal to BTE of diesel in a conventional engine. It is $3.3679 \%$ higher and $10.73 \%$ more compared to neat HOME operation in CI mode, which is $28 \%$. In addition, BTE for the validity test was $29.94 \%$ less than the RSM value. Similarly, for the above combinations, smoke, $\mathrm{HC}, \mathrm{CO}$, and NOx were reduced by $28.5 \%$ ( 66 to $47.1852 \mathrm{HSU}$ ), $38.12 \%$ (65 to $40.2222 \mathrm{ppm}$ ), $36.93 \%$ ( 0.35 to $0.220741 \%$ ), and by $15.26 \%$ (1009 to $855 \mathrm{ppm}$ ) compared to neat HOME operation in CI mode.

5. The assay of variances (ASOVA) revealed that this model could put forth the actual linkages among the outcomes and eloquent variables, with an acceptable overall or average determining coefficient $\mathrm{R} 2=0.9862$ of all responses, which directs that $98.62 \%$ of the adaptability for the responses could be described by the second-order polynomial predictors.

6. This optimized condition was validated by conducting an experiment and found similar results. 
7. The other experimental design values of FFD and RSM values can also be considered in actual implementation in engine applications, keeping in view the response to be optimized.

8. Response surface assay-based quadratic predictors can be used with ease to create the linkages among the independent parameters and dependent characteristics.

9. The validation of predicted outputs shows that the quadratic predictors are accurate enough and in good agreement.

10. The effect of provision of bridges and grooves on cylinder heads proves to be an important parameter to improve competence and curtail emissions, but some other variables, such as injection pressure, injection timing, compression ratio, nozzle geometry, and speed, etc., should be tested and assayed alongside them.

11. According to the validation of test emission results as per СРCB India, the European Union, and the USA, the emissions are less than or very close to the norms and are in general around $10 \mathrm{~g} / \mathrm{kW}-\mathrm{h}$, thus it can be stated that inlet valve masking (IVM) and number of piston grooves (NG) and cylinder head bridge-groove configuration (BGC) can be implemented for any diesel engines.

12. The major difference between the existing BS-IV and forthcoming BS-VI norms is the presence of diverse Sulphur compounds in the fuel. While the BS-IV fuel contains 50 parts per million (ppm) or $\mathrm{mg} / \mathrm{kg}$ Sulphur, the BS-VI grade fuel only has $10 \mathrm{ppm}$ or $\mathrm{mg} / \mathrm{kg}$ Sulphur content. The different compounds of Sulphur form $\mathrm{SO}_{2}$, and $10 \%$ of $\mathrm{SO} 3$ formed combines with water to form $\mathrm{H}_{2} \mathrm{SO}_{4}$ aerosols, combining with soot and dust to form particulate matter. Additionally, the harmful NOx (nitrogen oxides) from diesel cars has to be brought down by nearly $70 \%$. In the petrol cars, they can be reduced by $25 \%$. However, when we discuss air pollution, particulate matter, such as PM 2.5 (particles smaller than 2.5 microns) and PM 10 (particles smaller than 10 microns), are the most harmful components, and the BS VI will bring down the cancer-causing particulate matter in diesel cars by a phenomenal $80 \%$. As there is no Sulphur in BDF, there is no PM problem.

13. An IVM of $90^{\circ}$, a ' $\mathrm{NG}^{\prime}$ ' on piston 6, and 'BGC' with $2 \mathrm{~B} 3 \mathrm{G}$ model showed the highest NOx emissions of 855 ppm, which was $15.26 \%$ less contrasted with neat HOME utilized CI mode of working, which was 1009 and 900 ppm, respectively, with and without bridge-groove configuration. Lowered NOx emitted with other combinations may be linked to low combusting temperatures. It is to be noted that, for diesel engine simulation fueled with HOME, if we implement a combination of $1 \mathrm{~B} 2 \mathrm{G}$ cylinder head, 'IVM' of $30^{\circ}$ and 'NG' of 3 grooves on the piston optimizes a low $\mathrm{NO}_{\mathrm{x}}$ of $717.5 \mathrm{ppm}$ (BTE decreases slightly from $31.3679 \%$ to $23.5215 \%$ ). It is much less than that for neat HOME in a conventional engine, i.e., $1009 \mathrm{ppm}$. Hence, the percentage reduction of $\mathrm{NO}_{\mathrm{x}}$ is about $40.62 \%$. This suffices, to some extent, emission standards BS 6 and Euro 6 (to be implemented from April 2020), which are planning to reduce NOx by a staggering $70 \%$ compared to BS 4 and Euro 5. For the time being, this large reduction has not been made possible by engine research only, as reported by İbrahim Aslan Reşitoğlu et al. [18]. Thus, by using further On Board Equipment (OBE) and Real Driving Emissions (RDE) on all vehicles, enabling real-time tracking of emissions, diesel vehicles will include a Diesel Particulate Filter (DPF) and Selective Catalytic Reduction (SCR) technologies. With these design changes, NOx may be decreased towards $70 \%$. Additionally, by 2023, catalytic converters and misfire detectors are to be incorporated as per the (Automotive Research Association of India (ARAI), which is the leading automotive R\&D organization of the country, set up by the Automotive Industry with the Government of India.

14. For $100 \%$ HOME biodiesel with a combination of inlet valve masking (IVM) of $90^{\circ}$, number of piston grooves (NG) of 6 grooves on piston crown, and cylinder head bridge-groove configuration (BGC) of 2B 3G, CO emissions are considerably reduced from $46.0 \mathrm{~g} / \mathrm{kW}$-h to $17.65 \mathrm{~g} / \mathrm{kW}$-h if we take the last readings for a full load of $5.2 \mathrm{~kW}$, as given in Table 6. Thus, we can conclude that, for CO, BS VI norms cannot be satis- 
fied only from engine research, as also reported by İbrahim Aslan Reşitoğlu et al. [18], and may be satisfied by on board equipment such as a DOC (diesel oxidation catalyst).

Author Contributions: Conceptualization, M.R.I. and N.R.B.; methodology, K.G.R.; software, A.Y.P.; validation, M.R.I., A.Y.P., N.R.B. and K.G.R.; formal analysis, N.R.B.; investigation, M.R.I.; resources, T.M.Y.K. and S.J.; writing—original draft preparation, N.R.B.; writing—review and editing, T.M.Y.K.; supervision, N.R.B. project administration, S.J.; funding acquisition, T.M.Y.K. and S.J. All authors have read and agreed to the published version of the manuscript.

Funding: This work was funded by at King Khalid University under grant number R.G.P 1/197/41.

Institutional Review Board Statement: Not applicable.

Informed Consent Statement: Not applicable.

Data Availability Statement: Data sharing not applicable.

Acknowledgments: The author extends his appreciation to the Deanship of Scientific Research at King Khalid University for funding this work through research groups program under grant number (R.G.P 1/197/41).

Conflicts of Interest: The authors declare no conflict of interest.

$\begin{array}{ll}\text { Nomenclature } \\ \text { DOE } & \text { Designs of experiments } \\ \text { FFD } & \text { Full factorial designs } \\ \text { RSM } & \text { Response surface methodologies } \\ \text { ASTM } & \text { American Society for Testing and Materials } \\ \text { BTE } & \text { Brake thermal efficiency } \\ \text { BGC } & \text { Bridge-groove configuration } \\ \text { IVM } & \text { Inlet valve masking } \\ \text { CR } & \text { Compression ratio } \\ \text { SOC } & \text { Start of combustion } \\ \text { BDF } & \text { Biodiesel fuel } \\ \text { DICI } & \text { Direct injection compression ignition } \\ \text { IT } & \text { Injection timing } \\ \text { IOP } & \text { Injector opening pressure } \\ \text { EGR } & \text { Exhaust gas recirculation } \\ \text { TDC } & \text { Top dead center } \\ \text { bTDC } & \text { Before top dead center } \\ \text { a TDC } & \text { After top dead center } \\ \text { BSFC } & \text { Brake specific fuel consumption } \\ \text { ID } & \text { Ignition delay } \\ \text { CD } & \text { Combustion duration } \\ \text { NOx } & \text { Oxides of nitrogen } \\ \text { HC } & \text { Hydrocarbon } \\ \text { UBHC } & \text { Unburnt hydrocarbon } \\ \text { CO } & \text { Carbon monoxide } \\ \text { PM } & \text { Particulate matter } \\ \text { SI } & \text { Spark ignition } \\ \text { CA } & \text { Crank angle } \\ \text { PP } & \text { Peak pressure } \\ \text { HRR } & \text { Heat release rate } \\ \text { BTL } & \text { Burning time loss } \\ \text { EGT } & \text { Exhaust gas temperature } \\ & \\ \end{array}$




\section{References}

1. Agarwal, A.K.; Dhar, A.; Gupta, J.G.; Kim, W.I.; Choi, K.B.; Lee, C.S.; Park, S.W. Effect of fuel injection pressure and injection timing of Karanja biodiesel blends on fuel spray, engine performance, emissions and combustion characteristics. Energy Convers. Manag. 2015, 91, 302-314. [CrossRef]

2. Goldenberg, J.; Coelhobn, S.T. Renewable energy—Traditional biomass vs. modern biomass. Energy Policy 2004, 32, 711-714. [CrossRef]

3. Abuhabaya, A.; Fieldhouse, J.; Brow, D. The optimization of biodiesel production by using response surface methodology and its effect on compression ignition engine. Fuel Process. Technol. 2013, 113, 57-62. [CrossRef]

4. Singh, Y.; Sharma, A.; Tiwari, S.; Singla, A. Optimization of diesel engine performance and emission parameters employing cassia tora methyl esters-response surface methodology approach. Energy 2018, 168, 909-918. [CrossRef]

5. Ganapathy, T.; Murugesan, K.A.; Gakkhar, R.P. Performance optimization of Jatropha biodiesel engine model using Taguchi approach. Appl. Energy 2009, 86, 2476-2486. [CrossRef]

6. Raheman, H.; Phadatare, A.G. Diesel engine emissions and performance from blends of Karanja methyl ester and diesel. Biomass Bioenergy 2004, 27, 393-397. [CrossRef]

7. Hirkude, J.; Padalkar, A.; Shaikh, S.; Veigas, A. Effect of compression ratio on performance of CI engine fueled with biodiesel from waste fried oil using response surface methodology. Int. J. Energy Eng. 2013, 3, 227-233. [CrossRef]

8. Rao, K.P.; Rao, B.V.A. Parametric optimization for performance and emissions of an IDI engine with Mahua biodiesel. Egypt. J. Pet. 2017, 26, 733-743.

9. Berber, A. Mathematical model for fuel flow performance of diesel engine. Int. J. Automot. Eng. Technol. 2016, 5, 17-24. [CrossRef]

10. Najafi, G. Diesel engine combustion characteristics using nano-particles in biodiesel-diesel blends. Fuel 2018, 212, 668-678. [CrossRef]

11. Nayyar, A.; Sharma, D.; Soni, S.L.; Mathur, A. Characterization of n-butanol diesel blends on a small size variable compression ratio diesel engine: Modeling and experimental investigation. Energy Convers Manag. 2017, 150, 242-258. [CrossRef]

12. Hosmath, R.S.; Banapurmath, N.R.; Khandal, S.V.; Gaitonde, V.N.; Basavarajappa, Y.H. Effect of compression ratio, CNG flow rate and injection timing on the performance of dual fuel engine operated on honge oil methyl ester (HOME) and compressed natural gas (CNG). Renew Energy 2016, 93, 579-590. [CrossRef]

13. Khoobbakht, G.; Najafi, G.; Karimi, M.; Akram, A. Optimization of operating factors and blended levels of diesel, biodiesel and ethanol fuels to minimize exhaust emissions of diesel engine using response surface methodology. Appl. Therm. Eng. 2016, 99, 1006-1017. [CrossRef]

14. Kumar, B.R.; Saravanan, S.; Rana, D.; Nagendra, A. Combined effect of injection timing and exhaust gas recirculation (EGR) on performance and emissions of a DI diesel engine fueled with next-generation advanced biofuel-diesel blends using response surface methodology. Energy Convers Manag. 2016, 123, 470-486. [CrossRef]

15. Dhole, A.E.; Lata, D.B.; Yarasu, R.B. Effect of hydrogen and producer gas as secondary fuels on combustion parameters of a dual fuel diesel engine. Appl. Eng. 2016, 108, 764-773. [CrossRef]

16. Pandal, A.; Payri, R.; García-Oliver, J.M.; Pastor, J.M. Optimization of spray break-up CFD simulations by combining $\Sigma$-Y Eulerian atomization model with response surface methodology under diesel engine-like conditions (ECN Spray A). Comput. Fluids 2017, 156, 9-20. [CrossRef]

17. Pandian, M.; Sivapirakasam, S.P.; Udayakumar, M. Investigation on the effect of injection system parameters on performance and emission characteristics of a twin cylinder compression ignition direct injection engine fueled with pongamia biodiesel-diesel blend using response surface methodology. Appl. Energy 2011, 88, 2663-2676. [CrossRef]

18. Reşitoğlu, İ.A.; Altinişik, K.; Keskin, A. The pollutant emissions from diesel-engine vehicles and exhaust aftertreatment systems. Clean Technol. Environ. Policy 2015, 17, 15-27. [CrossRef]

19. Kaminaga, T.; Yamaguchi, K.; Ratnak, S.; Kusaka, J.; Youso, T.; Fujikawa, T.; Yamakawa, M. A study on combustion characteristics of a high compression ratio SI engine with high pressure gasoline injection. SAE Tech. Pap. 2019. [CrossRef]

20. Ratnak, S.; Kusaka, J.; Daisho, Y.; Yoshimura, K.; Nakama, K. Experiments and simulations of a lean-boost spark ignition engine for thermal efficiency improvement. SAE Int. J. Engines 2016, 9, 379-396.

21. Durakovic, B. Design of experiments application, concepts, examples: State of the art. Period. Eng. Nat. Sci. (PEN) 2017, 5, 421-439. [CrossRef]

22. di Blasio, G.; Viscardi, M.; Beatrice, C. DoE method for operating parameter optimization of a dual-fuel bio ethanol/diesel light duty engine. J. Fuels 2015, 2015, 674705. [CrossRef]

23. Win, Z.; Gakkhar, R.P.; Jain, S.C.; Bhattacharya, M. Parameter optimization of a diesel engine to reduce noise, fuel consumption, and exhaust emissions using response surface methodology. Proc. IMechE Part D J. Automob. Eng. 2005, 219, 1181-1192. [CrossRef]

24. Myers, R.H.; Montgomery, D.C.; Anderson-Cook, C.M. Response Surface Methodology; John Wiley \& Sons, Inc.: Hoboken, NJ, USA, 2009.

25. Ganapathy, T.; Gakkhar, R.P.; Murugesan, K. Optimization of performance parameters of diesel engine with Jatropha biodiesel using response surface methodology. Int. J. Sustain. Energy 2011, 30, 76-90. [CrossRef]

26. Adam, I.K.; Aziz, A.R.A.; Yusup, S. Determination of diesel engine performance fueled biodiesel (rubber seed/palm oil mixture) diesel blend. Int. J. Automot. Mech. Eng. IJAME 2015, 11, 2675-2685. [CrossRef]

27. Yaliwal, V.S.; Nataraja, K.M.; Banapurmath, N.R.; Tewari, P.G. Honge oil methyl ester and producer gas-fueled dual-fuel engine operated with varying compression ratios. Int. J. Sustain. Eng. 2013, 7, 330-340. [CrossRef] 